\title{
Medicinal Plant Diversity and Vegetation Analysis of Logged over Hill Forest of Tekai Tembeling Forest Reserve, Jerantut, Pahang
}

\author{
Norhajar Eswani, Kamziah Abd Kudus (Corresponding author), M. Nazre \& A.G. Awang Noor \\ Faculty of Forestry, University Putra Malaysia, 43400 Serdang, Selangor, Malaysia \\ Tel: 60-3-8946-7169Ｅ-mail: kamziah@putra.upm.edu.my
}

\author{
M. Ali \\ Perak State Forestry Department, Persiaran Meru Utama \\ 30020 Ipoh, Perak, Malaysia
}

The research is financed by Research University Grant Scheme, Universiti Putra Malaysia (03/01/07/0039RU)

\begin{abstract}
The study was carried out to analyze the species diversity and study of quantitative analysis of medicinal plants in logged over forest in Tekai Tembeling Forest Reserve (TTFR). Four plots of 1-hectare size each were established within the forest area. A total of 6788 individual medicinal trees and non trees representing 231 species, 179 genera and 87 families were recorded. The species area curve did not approach an asymptote condition. The regression equation to estimate species richness was $I n S=-0.47833+(0.377954 * \approx n(A))$ with $\mathrm{r}^{2}=0.95 \%$. The most diverse species for trees was Cinnamomum porrectum and Lygodium circinnatum for non trees. The most diverse plot was plot 2 with 7335 individuals and 188 species. Since the forest area was diverse in medicinal species, it is necessary to begin conservation assessment that will improve medicinal plants biodiversity.
\end{abstract}

Keywords: Species diversity, Importance value index (IVI), Medicinal plant

\section{Introduction}

Malaysia has been classified as one of the 12 megadiversity countries of the world. Altogether, these twelve megadiversity countries comprise at least $60 \%$ of the world's known species (Latiff, 2005). Plant has been used for ages for food, shelter, treat human disorders and disease. Malaysia has about 15,000 species of flowering plants of which about 10\% are said to be medicinal (Faridah Hanum et. al. 2001a, Faridah Hanum et. al. 2001b). Medicinal plant could be defined as plants which may have medicinal properties and many of them were collected from forest. Medicinal plants is one of the valuable non-timber in the forest. Traditional medicine is an important part in Malaysian culture and were practiced by ancestors long before the inroduction of modern medicine. The complete reports on the Malay traditional medicinal plants was reported by Burkill (1935) in a book entitled "A Dictionary of the Economic Products of the Malay Peninsula". Burkill (1935) provided the first comprehensive knowledge about the medicinal plants of Peninsular Malaysia, and that became the starting point for the phytochemists and ethnobotanist to do some studies and research relating to the medicinal plants. All of these works add a comprehensive knowledge to the account of the Malaysian medicinal plants. 'In conjunction with phytochemical screenings and chemical studies by the chemists, the above compilation attempted to introduce the diversity of medicinal plants to the Malaysian public was made. This is the key for future bioprospecting in Malaysia. It covers 135 families and more than 1000 species of medicinal plants. Those that are commonly used in traditional practices only cover about 103 families and 768 dicotyledonous species documented, and hence would definitely impeded the country's efforts to better and judiciously utilize them for the benefits of the populations' (A. Latiff, 2007). According to Tuan Marina et. al. (2007), there was high species richness, abundance and economic value of medicinal plants at Tranum Forest Reserved, Raub, Pahang. This forest categorized as hill forest. The most popular and high demanding of medicinal plants within this area are Phyllagathis rotundifolia, Labisia pumila, Mapania cuspidata, Homalomena sagittifolia, Peliosanthes teta and Tacca integrifolia. It proved that, hill forest also have abundance of medicinal plants to look at. This paper provides species diversity and quantitative analysis of medicinal plants in four hectare plots of hill forest of Tekai Tembeling Forest Reserve (TTFR), Jerantut, Pahang. The findings of this study indicate that TTFR is most 
diverse for medicinal plant such as Cinnamomum porrectum, Lygodium circinnatum, Globba sp., Labisia pumila and many else.

\section{Methodology}

\subsection{Study site}

This study were conducted at Tekai Tembeling Forest Reserve, Jerantut, Pahang. This is logged over hill dipterocarp forest and majority of the stocks are dipterocarp species. The fieldwork was carried out during May-December 2008. This forest area were logged over 2-5 years ago.

\subsection{Data collection}

Four plots each size 1 hectare were established at different elevation within the hill forest. Each of the 1 hectare plot were divided into 100 of $10 \times 10 \mathrm{~m}$ quadrates. The elevation range from 340a.s.1 - 520a.s.l. Data were gathered from each quadrates. Data collected were divided into two groups, tree and non-tree. Plants with diameter at breast height (dbh) more or equal to $5.0 \mathrm{~cm}$ were classified as tree while plants with dbh less than 5.0 $\mathrm{cm}$ were classified as non-tree. Parameters recorded for tree were species name, dbh and height. For non-tree species name and number of individuals were recorded. Dbh for trees were measured at $1.37 \mathrm{~m}$ above the ground level by using diameter tape. The height of trees were measured using laser hypsometer. All the specimens collected were brought to UPM herbarium for drying process and proceed to Forest Research Institute Malaysia (FRIM) for identification and verification by expert. Then, all the specimens were identified again according to Burkill (1935) to separate plant which possess medicinal value. Data on medicinal plants were recorded in database for statistical analysis.

\subsection{Data analysis}

Data collected were used to calculate frequency, density and basal area. Density, frequency and basal area of each species in each plot were calculated to seek importance value index (IVI). Vegetation analysis is the best way to study species composition and vegetation structure in one ecosystem and IVI were calculated in vegetation analysis (Bambang \& Ati, 2006). Importance Value Index (IVI) is the sum of relative density, relative dominance and relative frequency for a species and is calculated as follows (Curtis and Mclntosh, 1950). This formula were used to calculate IVI for trees only.

IVI of sp. $i=$ relative density of sp. $i+$ relative frequency of $s p . i+$ relative dominance of $s p . i$

where:

relative density $=\frac{(\text { no.tndivt ducals of spectes })}{\text { total indivt duals of all spectes }} * 100$

\section{relatlve frequency $=\frac{\text { frequency of specles } 1}{\text { to tal frequency values for all species }} * 100$}

rolative dominance $=\frac{\text { basal area of species i }}{\text { total basal area of all species }} * 100$

However, data on relative dominance which is derived from basal area is not possible for non-trees. According to Bambang and Ati (2006), IVI for undergrowth (non trees) calculated using formula modified as below:

IVI of sp. $\mathrm{i}=$ relative density of sp. $\mathrm{i}+$ relative frequency of $\mathrm{sp} . \mathrm{i}$

The Family Value Index (FVI) is the sum of relative density, relative frequency and relative dominance (tree only) for a family and was calculated using same formula as IVI, where species is replaced by family.

The data for computing species richness, evenness and diversity indices were analyzed using Ecological Methodology Software (Krebbs, 1998) formula.

2.3.1 Species richness

Jackknife estimate

$$
\hat{s}=s+(n-1 / n) k
$$

where; $\quad \hat{s}=$ jack knife estimate of species richness

$S=$ observed total number of species present in quadrates 


$$
\begin{aligned}
& n=\text { total quadrates } \\
& k=\text { unique species }
\end{aligned}
$$

\subsubsection{Species diversity}

Simpson's Index

$$
\begin{array}{ll} 
& \hat{D}=1-\sum P i^{2} \\
\text { where; } \quad & \hat{D}=\text { Simpson's index } \\
& P i=\text { proportion of species } i \text { in the community }
\end{array}
$$

Shannon-Weiner measure

$$
H^{\prime}=\sum_{i=1}^{s}(P i)(\log P i)
$$

where; $\quad H^{\prime}=$ inîformation content of sample (bits/individual) and index of diversity

$$
S=\text { number of species }
$$

$P i=$ proportion of total sample belonging to $i$ species

\subsubsection{Species evenness}

Simpson's measure of evenness

$$
E_{1 / D}=(1 / \hat{D}) / s
$$

where; $\quad E_{1 / D}=$ Simpson measure of evenness

$S=$ number of species in the sample

$\hat{D}=$ Simpson index

Smith and Wilson's index of evenness

$$
E_{v a r}=1-\left[2 f \left(\pi \arctan \left\{\sum_{i=1}^{z}\left(\log _{e}\left(n_{i}\right)-\sum_{i=1}^{z}\left(\frac{\log _{s}\left(n_{f}\right)}{s}\right)^{2} f s\right\}\right]\right.\right.
$$

where

$$
E_{\text {var }}=\text { Smith and Wilson's index of evenness }
$$

$n_{i}=$ Number of individuals in species $i$ in sample $(i=1,2, \ldots, s)$

$n_{j}=$ Number of individuals in species $j$ in sample $(j=1,2, \ldots, s)$

$s=$ Number of species in entire sample

\section{Results and discussion}

\section{(Note 1)}

Figure 1 showed the species accumulation curve constructed from the four 1-hectare plots. The number of medicinal plant species increase as the sample area increase but did not approach an asymptote condition. The actual number of species almost reach an asymptote condition. But the estimated number of species showed the number of species increase rapidly as the sample area increase and shows no signs to approach asymptotic condition. The estimated species richness plotted in Figure 1 followed the estimate regression equation $\boldsymbol{E} n \boldsymbol{S}^{\prime}=-0.47833+(0.377934 * \boldsymbol{Z} n(\boldsymbol{A}))$ with $\mathrm{r}^{2}=0.95 \%$.

\section{(Note 2)}

Table 1 showed most of the medicinal plant are from the group of tree, woody, climber and shrubs. 27 species from herbaceous, 14 from fern, 4 from palm and 3 from epiphyte. The largest group of tree, woody, climber and shrub represent $79.2 \%$ from all species occured.

\section{(Note 3)}

A total of 6,788 stems of medicinal plants comprising 231 species included in 179 genera and 87 families were identified from all four 1-ha plots. Most of the stems conquered by non-trees because the plots were logged over within 2-5 years ago, so it has lack number of large trees. The three most diverse families collected across all categories were Euphorbiaceae, Annonaceae and Rubiaceae. Most of these species families were represented by one genus and many species. These three families represent about $19.2 \%$ of the total species recorded in the study area. In terms of individuals composition, the study area was dominated by three most abundance medicinal tree species, namely Cinnamomum porrectum (Lauraceae), Garcinia scortechinii (Guttiferae) and Croton argyratus (Euphorbiaceae). For non trees the three most abundance medicinal species were Lygodium circinnatum 
(Schizaeaceae), Globba sp. (Zingiberaceae) and Croton argyratus (Euphorbiaceae). Appendix 1 showed the uses of each medicinal plants found in TTFR. The plants may be used internally or externally. The parts of plants used for medical purpose were leaves, roots, bark, stems and shoot. The use of medicinal plants for treatments such as skin disease, fever, coughs, post-natal mother, tonic and so many else. It were practised by our ancestors for many centuries ago and has been passed for every generations. These herbal medicine is an alternative remedy besides modern drugs. Nowadays, there were increasing of interest on value of medicinal plants. Possibly, the demand of these plants will increase as well for future health care needs (Shaharuddin, 2005).

(Note 4)

The distribution of dbh classes shown in Figure 2 conformed to a reverse ' $J$ ' shape curve with 359 individuals having dbh between 5.0-9.9 cm, 154 individuals of 10-14.9 $\mathrm{cm}$ dbh and 84 individuals of 15.0-19.9 $\mathrm{cm}$ dbh. The number of individuals with a diameter greater than $50 \mathrm{~cm}$ was 7 . In dbh range $5-9.9 \mathrm{~cm}$ showed plot 4 has the highest number of species compared to others. The number of medicinal plants which have dbh less than $5 \mathrm{~cm}$ was 6108 individuals. The reverse ' $\mathrm{J}$ ' shape size class distribution curve was obtained which is typical of all types of forests particularly in the logged-over forest where small trees emerges due to canopy openings in the forest area (Kunwar \& Sharma, 2004). Low pioneer vegetation dominated the area after logging. For trees the total number of medicinal plants is 674 while 6059 for non trees. The large proportion of medicinal plants with dbh less than $5 \mathrm{~cm}$ indicates that majority of the medicinal plants are undergrowth.

(Note 5)

Appendix 2 showed the quantitative analysis for medicinal trees with $\mathrm{dbh} \geq 5 \mathrm{~cm}$. A total of 99 medicinal tree species were observed from this study and the total of individual of trees is 674 . Three most diverse species were Cinnamomum porrectum, Garcinia scortechinii and Croton argyratus. However, when the study site were evaluated in terms of importance value index (IVI), the three most important species are Cinnamomum porrectum, Shorea leprosula and Ochanostachys amentaceae. The dominant and co-dominant species were Cinnamomum porrectum and Shorea leprosula, showing their values of IVI of 20.84 and 18.43 respectively and the highest (35 plants / 4ha) value of density was also recorded for Cinnamomum porrectum with their contributions to the study site were $5.17 \%$ of the total density, $4.87 \%$ of frequency, $10.81 \%$ of basal area and $6.95 \%$ of IVI. Co-dominant species contribute $3.10 \%$ of total density, $3.02 \%$ of frequency, $12.31 \%$ of basal area and $6.14 \%$ of IVI.

(Note 6)

The non trees composition from Appendix 3, shows a total of 228 medicinal species were recorded. The study area were dominated by five most abundance species namely, Lygodium circinnatum (183), Globba sp. (147), Labisia pumila (147), Tectaria singaporeana (142) and Croton argyratus (126). These five medicinal species represent about $12.3 \%$ of the total medicinal plants species from non trees which found in the four hectare plots. The IVI also indicates that the area was dominated by these five species.

(Note 7)

Referring to Appendix 4, the most five dominant family for tree were Lauraceae, Euphorbiaceae, Guttiferae, Dipterocarpaceae and Annonaceae. While, the less dominant family were Styracacea with FVI 0.39 and Menispermaceae with FVI 0.34. Appendix 5 indicates the highest value for FVI from non trees were dominated by five family such Euphorbiaceae, Annonaceae, Rubiaceae, Melastomataceae and Zingiberaceae. Family from Violaceae and Orchidaceae possess the same lowest value of FVI 0.03 .

\section{(Note 8)}

Figure 3 showed the dominance-diversity curve plotted between importance value index and species sequence for trees and non trees which indicates a relationship between different species showing importance value in study site. Species dominance related to the availability of suitable niche and resource apportionment in a community has often been interpreted from the dominance diversity curve (Kunwar \& Sharma, 2004). For trees, at the beginning, the curve quite steep because there were several species possess high IVI value than others, but then the curve moving consistent with gentle slope. The gentle slope of dominance diversity curve indicates steady growth of trees, while sharp depression of the curve representing the small size classes of trees is the results of human disturbance (logging). For non trees the curve is not very clear. The different between the IVI value also not obvious. Thus, indicates all the medicinal non trees contribute the same significant to the composition of medicinal plants within this study site. 


\subsection{Species Diversity}

(Note 9)

Referring to Table 2, the species diversity in four hectare plots of TTFR was calculated using Ecological Methodology Software (Krebbs, 1998). Comparison of the four plots in the study area showed the highest species diversity index $H^{\prime}=6.189$, plot 2 and plot 1 showed the lowest species diversity index $H^{\prime}$ of 4.632 . Shannon-Weiner index $\left(\mathrm{H}^{\prime}\right)$ was one of the most common indices used to evaluate forest diversity and the higher value of Shannon-Weiner's index indicates high species richness (Tuan Marina, et. al., 2007). Shannon-Weiner measure assumes that a random sample is taken from an infinitely large population and that all the species in the community population are represented in the sample (Robert, 1974). The average of diversity index for Shannon-Weiner measure was 5.708 (above 5.0) indicates high diversity. The Brillouin's index of diversity range from 4.56 to 6.108 and the Simpsons index (S) range from 0.869 to 0.976. Smith and Wilson's measure maximum evenness value were recorded in plot $3(0.38)$ while the minimum was registered at plot $2(0.243)$.

\section{Conclusion}

This study showed that TTFR has a diverse population of medicinal plants. A total of 6788 medicinal trees and non trees represented by 231 species, 179 genera and 87 family found within the study site. The most dominant medicinal tree was Cinnamomum porrectum (Lauraceae) while Lygodium circinnatum (Schizaeaceae) for non tree species. The most dense and diverse plot represent by plot 2 which comprise the greatest number of individuals and species. This paper concludes that a proper management from human disturbance and scientific management of medicinal plants of the forest area may lead a rich biodiversity site in Malaysia.

\section{Acknowledgements}

This study was conducted in collaboration with the Pahang State Forestry Department, Malaysia and was supported by Research University Grant Scheme (03/01/07/0039RU).

\section{References}

Bambang Hero Saharjo \& Ati Dwi Nurhayati. (2006). Domination and composition structure change at hemic peat natural regeneration following burning; A case study in Pelalawan, Riau Province. BIODIVERSITAS, 7(2), 154-158.

Burkill, I.H. (1935). Economic Products of Malay Peninsula. 2 vols. Crown Agent for the Colonies, London.

Curtis, J.T. \& McIntosh, R.P. (1950). An upland forest continuum in the prairie-forest border region of Wisconsin. Ecology, 32, 476-496.

Faridah Hanum, I., Ahmed Zainudin Ibrahim, Shamsul Khamis, M. Nazre, P. Lepun, G. Rusea, J.J. Lajuni \& A. Latiff. (2001a). An annotated checklist of higher plants in Ayer Hitam Forest Reserve, Puchong, Selangor. Pertanika Journal Tropical Agricultural Science, 24(1), 62-75.

Faridah Hanum, I., A. Rahim, P. Lepun, I. Edham \& M. Nazre (2001b). Tree taxa inventory at Ayer Hitam Forest Base-Camp. Pertanika Journal Tropical Agricultural Science, 24(1), 29-34.

Kamarudin, M.S. \& A. Latiff. (2002). Tumbuhan Ubatan Malaysia. Pusat Pengurusan Penyelidikan Universiti Kebangsaan Malaysia. ISBN: 983-2446-39-2.

Krebbs, C.J. (1998). Ecological Methodology. $2^{\text {nd }}$ edition. Addison-Wesley Educational Publishers, Inc. pp. 410-454.

Kunwar, R.M. \& Sharma, S.P. (2004). Quantitative analysis of tree species in two community forests of Dolpa district, mid-west Nepal. Himalayan Journal of Sciences, 2(3), 23-28.

Latiff, A. (2007). Forestry, forest resources and forest biodiversity conservation in Peninsular Malaysia. Proceedings of the National Conference on the Management and Conservation of Forest Biodiversity in Malaysia. pp. 167-184.

Latiff, A. (2005). Valuing the biodiversity of medicinal plant species in Malaysia. Sustainable Managemnet and Utilization of Medicinal Plant Resources in Proceedings of the International Conference on Medicinal Plants. pp. 3-16.

Robert, W. P. (1974). An introduction to quantitative ecology. International student edition. McGraw-Hill series in population biology. ISBN: 0-07-050415-6.

Shaharuddin bin Mohamad Ismail. (2005). Medicinal plant resources from the forests of peninsular Malaysia: Issues and challenges. Sustainable Managemnet and Utilization of Medicinal Plant Resources in Proceedings of the International Conference on Medicinal Plants. pp. 51-66. 
Tuan Marina, T.I., Awang Noor, A.G. \& Faridah Hanum, I. (2007). Species diversity and economic value of medicinal plants in five-hectare plots of hill dipterocarp forest, Pahang. Proceedings of the National Conference on the Management and Conservation of Forest Biodiversity in Malaysia. pp. 414-426.

\section{Notes}

Note 1. Figure 1 is placed here

Note 2. Table 1 is placed here

Note 3. Appendix 1 is placed here

Note 4. Figure 2 is placed here

Note 5. Appendix 2 is placed here

Note 6. Appendix 3 is placed here

Note 7. Appendix 4 and Appendix 5 is placed here

Note 8 . Figure 3 is placed here

Note 9. Table 2 is placed here

Table 1. Number of species by class

\begin{tabular}{|l|c|}
\hline $\begin{array}{c}\text { Category of } \\
\text { plant }\end{array}$ & no. of species \\
\hline $\begin{array}{l}\text { tree/ woody/ } \\
\text { climber/ shrub }\end{array}$ & 183 \\
\hline herbaceous & 27 \\
\hline fern & 14 \\
\hline palm & 4 \\
\hline epiphyte & 3 \\
\hline TOTAL & 231 \\
\hline
\end{tabular}

Table 2. Diversity indices of Tekai Tembeling Forest Reserve

\begin{tabular}{|l|l|l|l|l|}
\hline $\begin{array}{c}\text { Diversity } \\
\text { indices }\end{array}$ & \multicolumn{1}{|c|}{ Plot 1 } & \multicolumn{1}{c|}{ Plot 2 } & \multicolumn{1}{c|}{ Plot 3 } & \multicolumn{1}{c|}{ Plot 4 } \\
\hline $\mathrm{N}$ & 4850 & 7335 & 2513 & 3119 \\
\hline $\mathrm{S}_{\mathrm{obs}}$ & 116 & 188 & 121 & 133 \\
\hline $\mathrm{R}$ & 129.9 & 223.6 & 136.8 & 151.8 \\
\hline $\mathrm{H}$ & 4.560 & 6.108 & 5.876 & 5.866 \\
\hline $\mathrm{H}$, & 4.632 & 6.189 & 6.019 & 5.993 \\
\hline $\mathrm{S}$ & 0.869 & 0.976 & 0.976 & 0.975 \\
\hline E & 0.267 & 0.243 & 0.380 & 0.322 \\
\hline
\end{tabular}




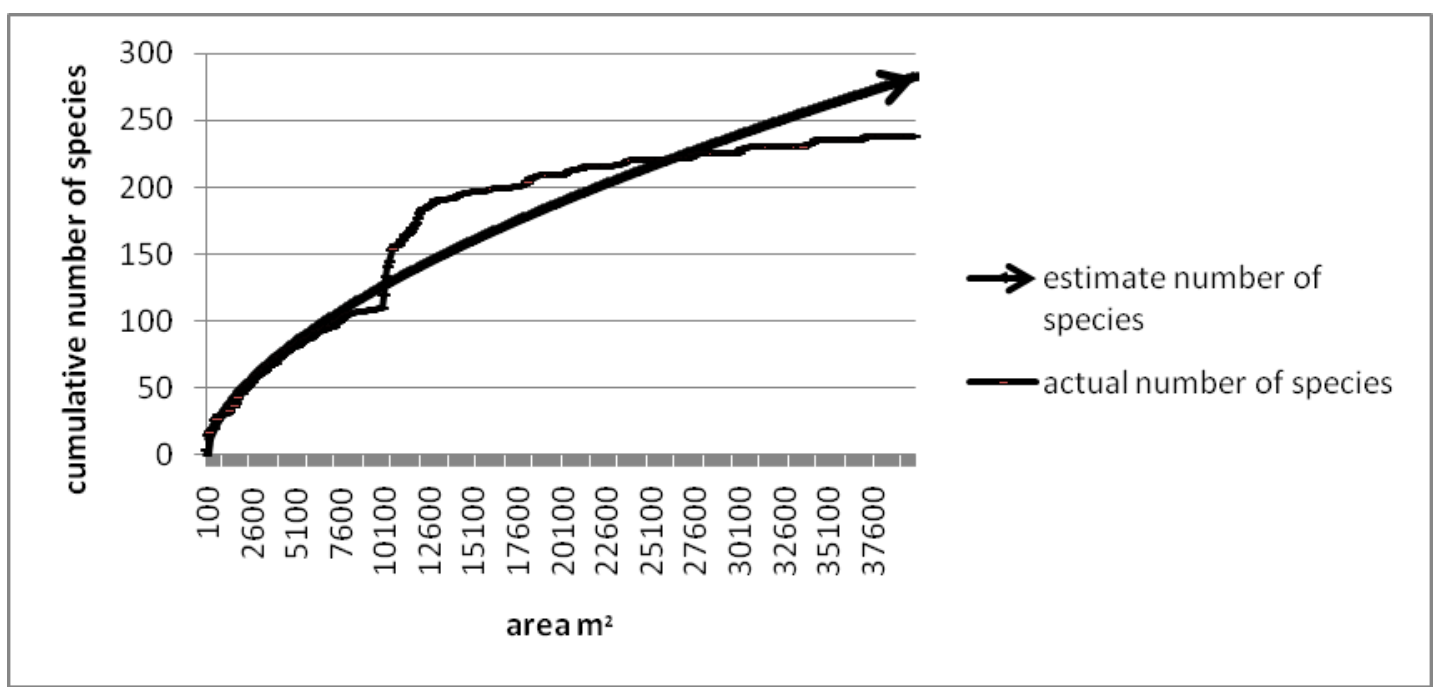

Figure 1. Species area curve

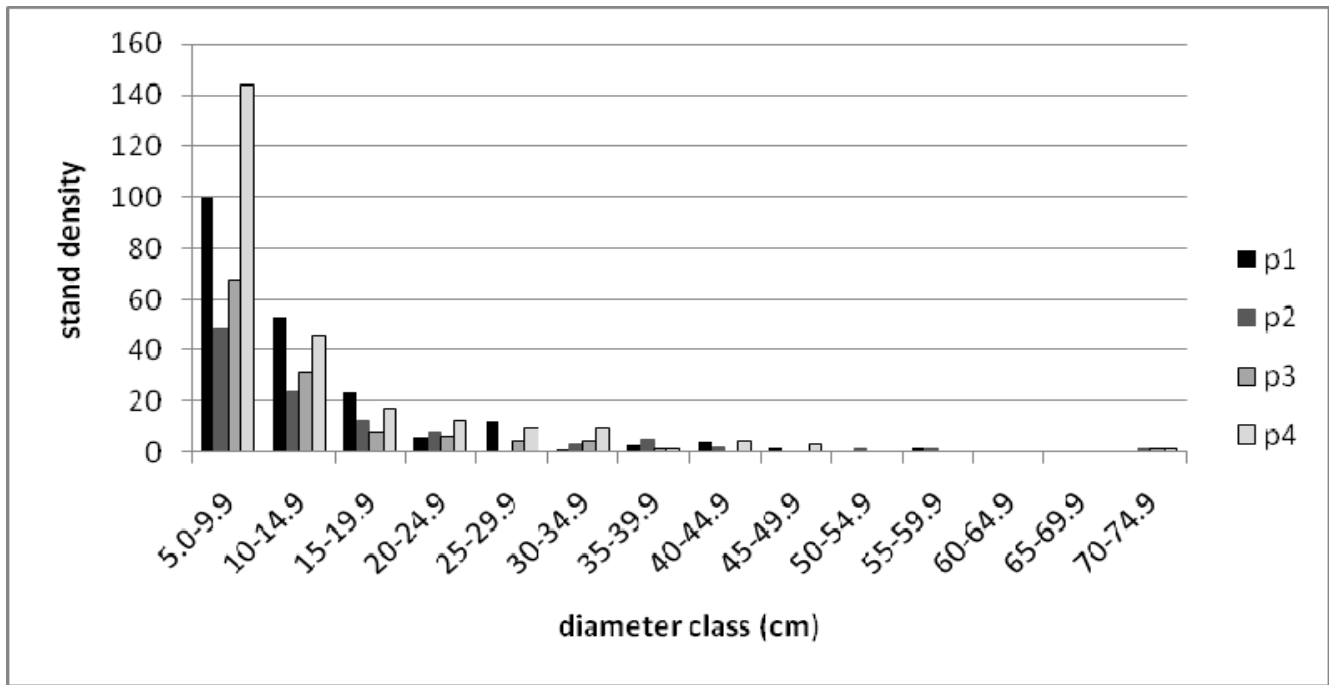

Figure 2. Distribution of medicinal plants in different size classes

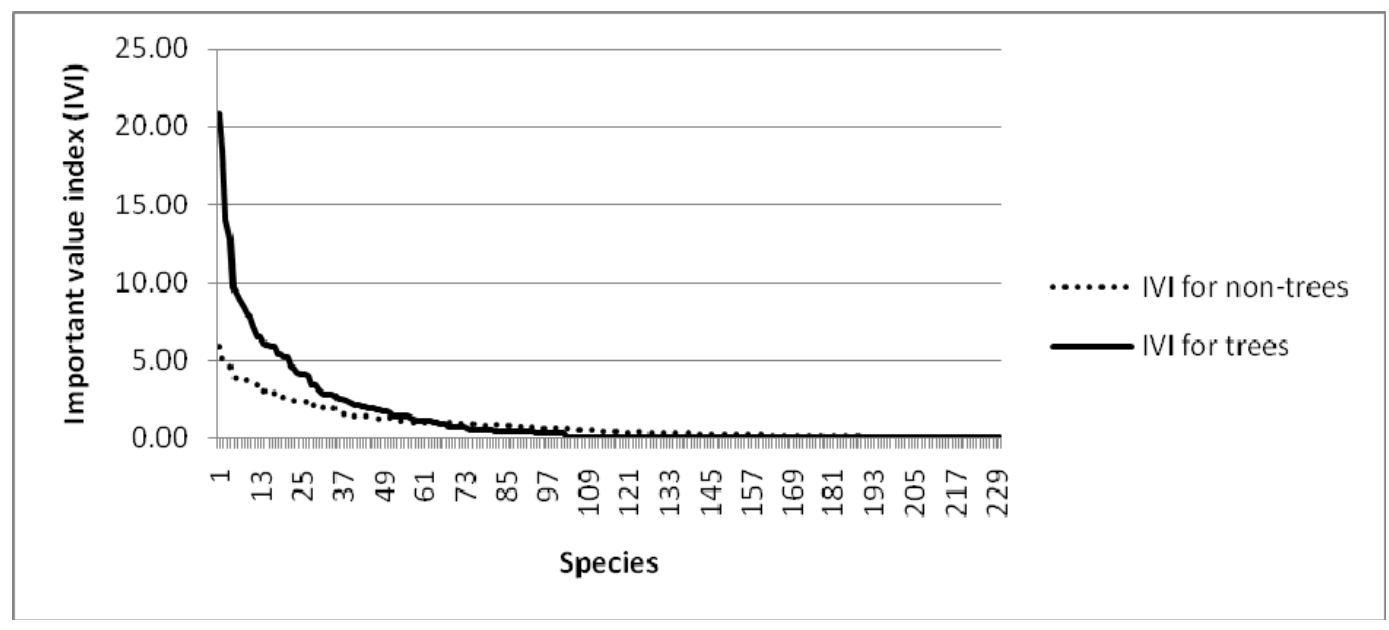

Figure 3. Dominance diversity curve for the medicinal plants (trees and non trees) 
Appendix 1. Uses of medicinal plants in TTFR based on Burkil (1935) and Kamarudin \& Latiff (2002)

\begin{tabular}{|c|c|c|}
\hline NO. & SPECIES NAME & USES \\
\hline 1 & Acrotrema costatum & protective medicine for women after childbirth. \\
\hline 2 & Agelaea macrophylla & rheumatism and in an aphrodisiac with smilax \\
\hline 3 & Agrostistachys longifolia var & for tooth-ache \\
\hline 4 & Albizzia splendens & diarrhoea \\
\hline 5 & Alpinia malaccensis & sores \\
\hline 6 & Alstonia augustiloba & for remittent fever \\
\hline 7 & Amischotolype griffithii & fever \\
\hline 8 & Amischotolype molissima & to treat malarial fever \\
\hline 9 & Ancistrocladus tectorius & dysentery and malaria \\
\hline 10 & Antidesma montanum & for headache in children, for measles, chicken-pox and malaria \\
\hline 11 & Aralidium pinnatifitidum & fever, rheumatism \\
\hline 12 & Ardisia crenata & applied to the skin for scurf, ear-ache and orchitis \\
\hline 13 & Ardisia villosa & for dropsyand jungle fevers. \\
\hline 14 & Arenga pinnata & for stone in the bladder, phthisis, dysentery and lactagogue. \\
\hline 15 & Artabotrys grandifolius & treatment after childbirth \\
\hline 16 & Artocarpus elasticus & dysentery, for poulticing ulcers and prevents conception. \\
\hline 17 & Asplenium nidus & for washing hair and to facilitate giving birth \\
\hline 18 & Baccaurea brevipes & to regulate menstruation \\
\hline 19 & Baccaurea parviflora & to ease urinating \\
\hline 20 & Barringtonia scortechinii & the fruit are edible and the seed used as a spice to flavour food. \\
\hline 21 & Bauhinia bidentata & given internally to women for nervous complaints and treatment of toothache \\
\hline 22 & Blechnum orientale & urinary complaints and for dropsy. \\
\hline 23 & Bouea macrophylla & poultice for headache and for thrush \\
\hline 24 & Breynia discigera & poulticing over the kidneys. \\
\hline 25 & Bridelia tomentosa & for colic, stomacache and for fever \\
\hline 26 & Callicarpa candicans & for abdominal troubles, for bringing on the menses and for poulticing wounds \\
\hline 27 & Calophyllum rubiginosum & for itch and other skin complaints \\
\hline 28 & Calophyllum wallichianum & for itch and other skin complaints \\
\hline 29 & Campylospermum serratum & for dysentery and for fever \\
\hline 30 & Carallia brachiata & the leaves for treatment in sapraemia. The bark is employed in the treatment of \\
\hline 31 & Carallia suffruticosa & for worms, coughs, after childbirth as protective medicine and for bathing in \\
\hline 32 & Cayratia molissima & pouticing swellings \\
\hline 33 & Chassalia chartacea & malaria, coughs, childbirth, cuts, wounds and ulcers. \\
\hline 34 & Chrysophyllum roxburgii & the fruit can be eaten \\
\hline 35 & Cinnamomum porrectum & tonic \\
\hline 36 & Cinnamomum javanicum & after childbirth \\
\hline 37 & Cinnamomum sintoc & diarrhoea and other intestinal complaints. As vermifuge. Also used for \\
\hline 38 & Clerodendron deflexum & for fever and bowel complaints \\
\hline 39 & Clerodendron laevifolium & contains saponin which beneficial to human body. \\
\hline 40 & Clidemia hirta & used as antidote \\
\hline 41 & Cnestis palala & for stomacache, after childbirth,malaria and gonorrhoea. \\
\hline 42 & Colocasia esculenta & for wounds, including snake bites. \\
\hline 43 & Combretum sundaicum & for head ache \\
\hline 44 & Connarus ferrugineus & as antiseptic for skin complaints \\
\hline 45 & Coptosapelta griffithii & for colic and fevers \\
\hline 46 & Coptosapelta parviflora & for colic and fevers \\
\hline 47 & Coscinium fenestratum & poultice cuts and sores with it. \\
\hline 48 & Costus speciocus & colds, rheumatism, pneumonia, tonic, depurative, small pox, coughs, \\
\hline 49 & Cratoxylum cochinchinensis & for colic, itch, skin complaints and stomach-ache. \\
\hline 50 & Cratoxylum formosum & used for antioxidants. \\
\hline
\end{tabular}




\begin{tabular}{|c|c|c|}
\hline 51 & Croton argyratus & to cure purging, diarrhoea and after childbirth. \\
\hline 52 & Croton laevifolium & after childbirth \\
\hline 53 & Ctenolophon parvifolius & cooling lotion for elephants \\
\hline 54 & Cyathea mollucana & for sores on the legs. \\
\hline 55 & Cyrtandra capulata & after childbirth and cure fever \\
\hline 56 & Cyrtandromoea grandis & fever \\
\hline 57 & Dalbergia pinnata & for varicose veins, nervous disorders, itch and an embrocation for coughs \\
\hline 58 & Desmos chinensis & dysentery or after childbirth and for vertigo \\
\hline 59 & Didisandra wrayii & a genus of herbs. \\
\hline 60 & Diospyros argenteum & applying in herpes \\
\hline 61 & Diospyros buxifolia & treat venereal disease, diabetes and whiteness \\
\hline 62 & Diospyros lanceifolia & cure ill waist. \\
\hline 63 & Diospyros latisepala & venereal disease \\
\hline 64 & Diospyros sumatrana & used as a protective medicine after childbirth \\
\hline 65 & Dipteris conjugata & in lower Siam its roots are eagerly collected as being of medicinal value \\
\hline 66 & Dissochaeta celebica & affords an 'ubat meroyan'. \\
\hline 67 & Dissochaeta intermedia & after childbirth as protective medicine. \\
\hline 68 & Donax grandis & snake bites, to sore eyes and for blood poisoning \\
\hline 69 & Donax parviflorus & snake bites, to sore eyes and for blood poisoning \\
\hline 70 & Dryobalanops aromatica & treat wound, tooth-ache, stomach-ache, head-ache, eye complaints and urinary \\
\hline 71 & Dysoxylum cauliflorum & for rheumatism and for abdominal pains \\
\hline 72 & Elaeocarpus floribundus & used as a mouth-wash for inflamed gums \\
\hline 73 & Elaeocarpus nitidus & the fruit eaten by local in Sabah \\
\hline 74 & Embelia ribes & as an anthelmintic, alterative, tonic, coughs and diarrhoea \\
\hline 75 & Entada rheedei & for itch, abdominal complaints, colic and severe internal complaints. \\
\hline 76 & Epipremnum giganteum & treat ulcerated nose. \\
\hline 77 & Epiprinus malayanus & for healthy and ageless. \\
\hline 78 & Erycibe albida & used chiefly in childbirth \\
\hline 79 & Eurycoma longifolia & used as a febrifuge, for internittent fever, for childbirth, head-ache,wounds, \\
\hline 80 & Euthemis leucocarpa & the roots used medicinally \\
\hline 81 & Fagerlindia fasciculata & for poulticing sores \\
\hline 82 & Fagraea acuminatissima & as a poultice in fever and head-ache \\
\hline 83 & Fagraea fragrans & for passing blood in stools and for malaria \\
\hline 84 & Fagraea racemosa & a tonic after fever, for pains in the loins, for curing fever in children. Boiled \\
\hline 85 & Fibraurea tinctoria & after childbirth, dysentery, diabetes and for treating ulcerated noses. \\
\hline 86 & Ficus hispida & for fever, after childbirth, stomach-ache in children, fever, diarrhoea and \\
\hline 87 & Fissistigma lanuginosum & after childbirth and for stomach-ache \\
\hline 88 & Flacourtia rukam & for diarrhoea, dysentery, dysmenorrhoea, to inflamed eye-lids and for small \\
\hline 89 & Forrestia griffithii & for fever \\
\hline 90 & Friesodielsia affinis & for ringwormh \\
\hline 91 & Galearia fulva & for gonorrhoea \\
\hline 92 & Garcinia atroviridis & after confinement and for ear-ache \\
\hline 93 & Garcinia griffithii & for abortion. \\
\hline 94 & Garcinia nigrolineata & used in making a lotion for running eyes \\
\hline 95 & Garcinia scortechinii & curing cuts \\
\hline 96 & Gironniera hirta & after childbirth as a protective medicine \\
\hline 97 & Globba patens & used as a protective medicine (meroyan) after childbirth. \\
\hline 98 & Globba sp. & Cure a fever and ability to give invulnerability \\
\hline 99 & Gnetum gnemon & the fruit use to prevent constipation \\
\hline 100 & Gnetum tenuifolium & after childbirth \\
\hline 101 & Goniothalamus macrophylla & for colds, fever, administering after childbirth, applied to swelling and \\
\hline 102 & Goniothalamus malayanus & used to treat small-pox and arthritic illness \\
\hline
\end{tabular}




\begin{tabular}{|c|c|c|}
\hline 103 & Gynotroches axillaris & for poulticing the head in fever \\
\hline 104 & Hanguana malayana & pain in the bones. \\
\hline 105 & Henckelia platypus & coughs \\
\hline 106 & Homalomena sp. & after childbirth and another is for the poulticing of yaws-sores \\
\hline 107 & Hoya sp. & tonic \\
\hline 108 & Hulettia dumosa & for all disease of the abdomen and to the gums for tooth-ache \\
\hline 109 & Hydnocarpus castanea & for internal disorders and skin disease \\
\hline 110 & Intsia palembanica & given to men who have become demented by reason of elephant spirits \\
\hline 111 & Ixonanthes icosandra & head-ache, cough \\
\hline 112 & Ixonanthes reticulata & used as potion (ubat pengasih) \\
\hline 113 & Labisia Pumila & after childbirth as a protective medicine, to expedite labour, for flatulence, \\
\hline 114 & Lansium domesticum & to cuts, ulcers, swellings, for rheumatism \\
\hline 115 & Lasianthus oblongus & after childbirth \\
\hline 116 & Leea indica & skin complaints, including caterpillar itch, poulticing for body pains and for \\
\hline 117 & Lepidagathis sp. & coughs, to procure abortion during the first three month of pregnancy. \\
\hline 118 & Lepisanthes tetraphylla & coughs and for bathing for fever \\
\hline 119 & Leptonychia caudata & during childbirth, for fever, ulcerated noses and cooling lotion in fever. \\
\hline 120 & Litsea elliptica & it supplies the 'perawas' bark of native medicines and very aromatic \\
\hline 121 & Litsea grandis & applied to wounds. \\
\hline 122 & Litsea lancifolia var lancifolia & the leaves are used for poulticing boils. \\
\hline 123 & Luvunga scandens & to reduce malaria fever. \\
\hline 124 & Lycopodiella cernua & lotion in beri-beri, coughs and uneasiness of the chest \\
\hline 125 & Lygodium circinnatum & protective medicines after childbirth and for wounds. \\
\hline 126 & Macaranga conifera & for malaria and dopsy. \\
\hline 127 & Macaranga gigantea & for diarrhoea and dysentery \\
\hline 128 & Macaranga hypoleuca & used as a febrifuge, expectorant and anti-spasmodic \\
\hline 129 & Macaranga triloba & for stomach-ache and poultice boils on the head. \\
\hline 130 & Maclurodendron porteri & to treat high blood pressure. \\
\hline 131 & Maesa ramentacea & for itch, other skin disease and for pain at the heart. \\
\hline 132 & Mallotus macrostachys & for cleansing wounds, fever \\
\hline 133 & Mapania palustris & has cooling properties. Good for kidney. \\
\hline 134 & Medusanthera gracilis & for rheumatism and used to blacken teeth \\
\hline 135 & Melastoma malabathricum & for diarrhoea, dysentery, women after childbirth, used for leucorrhoea, \\
\hline 136 & Memecylon dichotomum & lotion for rheumatism, for vertigo and is given internally after childbirth \\
\hline 137 & Memecylon minutiflorum & one of the 'rempah ratus' or hundred ingredients given after childbirth \\
\hline 138 & Merremia peltata & for stomach-ache, for coughs, diarrhoea, worms, sore eyes, for washing hair \\
\hline 139 & Mesua ferrae & poulticing wounds, draught taken after childbirth \\
\hline 140 & Mezettia leptopoda & used for strengthen energy and maintain health \\
\hline 141 & Microcos fibrocarpa & the pulped use in cooking. \\
\hline 142 & Microcos latifolia & the fruit use in cooking. \\
\hline 143 & Mitrella kentii & for fever \\
\hline 144 & Molineria capitulata & one of the several drugs to be sprinkled over the body of an elephant to cure \\
\hline 145 & Molineria latifolia & for menorrhagia or used as lotion in ophthalmia, fever, used as a stomachic \\
\hline 146 & Murraya paniculata & for blistered in stomach, tooth-ache, tonic and for tapeworm problem. \\
\hline 147 & Mussaenda sp. & asthma, recurrent fevers and dropsy. \\
\hline 148 & Nephrolepis auriculata & itch and used for treat hypertension. \\
\hline 149 & Ochanostachys amentacea & for fever, after childbirth and rheumatic fever \\
\hline 150 & Oncosperma horridum & fever \\
\hline 151 & Paramignya lobata & to facilitate labour. \\
\hline 152 & Parkia speciosa & prevent diabetes, kidney relating problem, hypertension, stomach-ache and to \\
\hline 153 & Payena lucida & after childbirth \\
\hline 154 & Peliosanthes teta & treating diarrhoea \\
\hline
\end{tabular}




\begin{tabular}{|c|c|c|}
\hline 155 & Pentaspadon motleyi & for itch and similar skin disease. kill the parasites but set up great irritation in \\
\hline 156 & Peperomia sp. & anti-rheumatic and head-ache. \\
\hline 157 & Phyllanthus emblica & fever, dysentery, head-ache, vertigo, dyspepsia, as a diuretic, conjunctivitis, \\
\hline 158 & Pimelodendron griffithianum & fruit edible. \\
\hline 159 & Pinanga disticha & an antidote to poison ingested \\
\hline 160 & Piper sarmentosum & to cure weakness and pains in the bones, head-ache, for 'panau' or \\
\hline 161 & Pittosporum ferrugineum & malaria \\
\hline 162 & Pleocnemia irregularis & cure diarrhoea and skin complaints. \\
\hline 163 & Plocoglottis javanica & for ear-ache. \\
\hline 164 & Podocarpus polystachyus & as a alternative in rheumatism and for painful joints. \\
\hline 165 & Poikilospermum sp. & prescribes leaves for application to an abscess or carbuncle before and roots \\
\hline 166 & Polyalthia glauca & give to women after chilbirth to shrink the uterus. \\
\hline 167 & Polyalthia hypoleuca & after childbirth as a protective medicine (ubat meroyan) \\
\hline 168 & Polyalthia sumatrana & the plants used for head-ache \\
\hline 169 & Pometia pinnata & fever and to festering sores \\
\hline 170 & Popowia tomentosa & ingredient for poison. \\
\hline 171 & Porterandia anisophyllea & for itch and abortion. \\
\hline 172 & Prunus arborea var arborea & the bitter bark tasting like laurel is medicinal. There is glucoside in it like \\
\hline 173 & Psydrax nitidum & f diarrhoea. Hydrocyanic acid occurs in the leaves. \\
\hline 174 & Pteris ensiformis & for cleansing unhealthy tongues of children and for glandular swelling of the \\
\hline 175 & Pternandra coerulescens & for poulticing in orchitis or hydrocele, for vomiting and administered after \\
\hline 176 & Pternandra echinata & for coughs and asthma. \\
\hline 177 & Pyramidanthe prismatica & for diarrhoea and snake-bite \\
\hline 178 & Pyrenaria acuminata & for sores on the legs. \\
\hline 179 & Rhodamnia cinerea & after chilbirth, protective medicine, for stomach-ache and used as a poultice \\
\hline 180 & Rinorea anguifera & as a protective draught after childbirth. \\
\hline 181 & Rourea acutipetala var acutipetala & for lumbago. \\
\hline 182 & Rourea mimosoides & colic, leprosy, as an 'ubat meroyan' after childbirth and to children for colds. \\
\hline 183 & Rourea rugosa & for constipation and apparently it is resorted to freely. \\
\hline 184 & Salacca glabrescens & fruit edible. \\
\hline 185 & Salacia grandiflora & after childbirth. \\
\hline 186 & Sandoricum koetjape & one of the rempah ratusas a protective medicine after childbirth, for remittent \\
\hline 187 & Santiria griffithii & prescribed for rheumatism. \\
\hline 188 & Sapium baccatum & to treat 'bisul'. \\
\hline 189 & Saraca cauliflora & the fruit is used medicinally. \\
\hline 190 & Sauropus androgynus & for fever and for stricture of the bladder. \\
\hline 191 & Scaphium linearicarpum & as a febrifuge. \\
\hline 192 & Scaphium macropodum & for fever and dysentery. \\
\hline 193 & Schima wallichii & one of the 'rempah ratus' infused to make a draught for a mother after \\
\hline 194 & Selaginella intermedia & for stomach-ache, rheumatism and asthma. \\
\hline 195 & Selaginella plana & to stop bleeding. \\
\hline 196 & Selaginella wallichii & as a protective medicine after childbirth \\
\hline 197 & selaginella wildenowii & for high fever, for pains in the back, tonic medicine and poultices for skin \\
\hline 198 & Shorea leprosula & a tonic for adolescent. \\
\hline 199 & Sindora coriacea & wood-oil is used for medicinal purposes. \\
\hline 200 & Sindora wallichii & Use after childbirth. \\
\hline 201 & Smilax megacarpa & the juice is given to a child at birth. \\
\hline 202 & Smilex sp. & after childbirth. \\
\hline 203 & Spatholobus ferrugineus & for colic and after childbirth, for irregular menstruation, uterine haemorrhage, \\
\hline 204 & Sticherus truncatus & useful in healing high fever. \\
\hline 205 & Styrax benzoin & used for asthma in children. \\
\hline 206 & Symplocos crassipes var penangiana & for stomach-ache. \\
\hline
\end{tabular}




\begin{tabular}{|c|c|c|}
\hline 207 & Symplocos rubiginosa & for swollen spleen. \\
\hline 208 & Syngramma alismifolia & Used as a substitute for Helminthostachys (as a tonic, for fever, medicine for \\
\hline 209 & Syzygium polyanthum & for diarrhoea and for itch. \\
\hline 210 & Tacca integrifolia & as a poultice for a rash due to irritant hairy caterpillars. \\
\hline 211 & Taenitis blechnoides & use as protective medicine (ubat meroyan) after childbirth. \\
\hline 212 & Tectaria singaporeana & cure for fever and a post-natal tonic. \\
\hline 213 & Tetracera indica & for itch. \\
\hline 214 & Tetracera scandens & after childbirth also given in dysentery, diarrhoea, for burns and for coughs. \\
\hline 215 & Thottea corymbosa & for tooth-ache and as a diuretic during confinement. \\
\hline 216 & Thottea tomentosa & for poulticing skin complanits, Snake bites and for coughs. \\
\hline 217 & Tinomiscium petiolare & for rheumatism. \\
\hline 218 & Toona sp. & for dysentery, poultices to wounds. \\
\hline 219 & Trema orientalis & for sore tongue, for diarrhoea and the passing of blood in the urine. \\
\hline 220 & Uncaria cordata & used for sores and callus. \\
\hline 221 & Urophyllum glabrum & for fever. \\
\hline 222 & Uvaria grandiflora & to warm children body, after childbirth, stomach-ache, tooth-ache, scabies and \\
\hline 223 & Ventilago sp. & tonic \\
\hline 224 & Xanthophyllum amoenum & the fruit used for head skin itch and remove danddruff. \\
\hline 225 & Ximenia americana & for colic. \\
\hline 226 & Xylopia ferruginea & to stop vomiting. \\
\hline 227 & Xylopia malayana var obscura & one of the hundred ingredients (rempah ratus) given to a women after \\
\hline 228 & Zingiber griffithii & used for poulticing, for giddiness, fever and cure asthma. \\
\hline 229 & Zingiber officinale & ginger taken into stomach is a warm, stimulating carminative and when \\
\hline 230 & Zingiber spectabile & for poulticing swelling and for bathing eyes with inflamed lids. \\
\hline 231 & Ziziphus kunstleri & administered after childbirth. \\
\hline
\end{tabular}

Appendix 2. Quantitative analysis of vegetation of medicinal plants (trees) in TTFR

\begin{tabular}{|c|c|c|c|c|c|c|c|c|c|}
\hline No. & Species name & Family & D & $\mathbf{F}$ & BA & RD (\%) & RF (\%) & RBA (\%) & IVI \\
\hline 1 & Cinnamomum porrectum & Lauraceae & 35 & 29 & 1.542 & 5.19 & 4.89 & 10.85 & 20.93 \\
\hline 2 & Shorea leprosula & Dipterocarpaceae & 21 & 18 & 1.756 & 3.12 & 3.04 & 12.36 & 18.51 \\
\hline 3 & Ochanostachys amentacea & Olacaceae & 15 & 14 & 1.356 & 2.23 & 2.36 & 9.54 & 14.13 \\
\hline 4 & Garcinia scortechinii & Guttiferae & 30 & 27 & 0.538 & 4.45 & 4.55 & 3.79 & 12.79 \\
\hline 5 & Elaeocarpus floribundus & Elaeocarpaceae & 23 & 22 & 0.367 & 3.41 & 3.71 & 2.58 & 9.70 \\
\hline 6 & Xanthophyllum amoenum & Polygalaceae & 21 & 20 & 0.398 & 3.12 & 3.37 & 2.80 & 9.29 \\
\hline 7 & Croton argyratus & Euphorbiaceae & 29 & 20 & 0.182 & 4.30 & 3.37 & 1.28 & 8.96 \\
\hline 8 & Cinnamomum javanicum & Lauraceae & 20 & 16 & 0.396 & 2.97 & 2.70 & 2.79 & 8.45 \\
\hline 9 & Mallotus macrostachys & Euphorbiaceae & 22 & 15 & 0.314 & 3.26 & 2.53 & 2.21 & 8.01 \\
\hline 10 & Memecylon minutiflorum & Melastomataceae & 21 & 18 & 0.231 & 3.12 & 3.04 & 1.63 & 7.78 \\
\hline 11 & Scaphium linearicarpum & Sterculiaceae & 14 & 13 & 0.423 & 2.08 & 2.19 & 2.98 & 7.25 \\
\hline 12 & Mesua ferrae & Guttiferae & 13 & 13 & 0.340 & 1.93 & 2.19 & 2.39 & 6.51 \\
\hline 13 & Rhodamnia cinerea & Myrtaceae & 18 & 13 & 0.233 & 2.67 & 2.19 & 1.64 & 6.50 \\
\hline 14 & Artocarpus elasticus & Moraceae & 5 & 5 & 0.642 & 0.74 & 0.84 & 4.52 & 6.11 \\
\hline 15 & Flacourtia rukam & Flacourtiaceae & 16 & 16 & 0.131 & 2.37 & 2.70 & 0.92 & 5.99 \\
\hline 16 & Baccaurea parviflora & Euphorbiaceae & 17 & 16 & 0.097 & 2.52 & 2.70 & 0.68 & 5.90 \\
\hline 17 & Hydnocarpus castanea & Flacourtiaceae & 8 & 7 & 0.499 & 1.19 & 1.18 & 3.51 & 5.88 \\
\hline 18 & Xylopia ferruginea & Annonaceae & 12 & 12 & 0.226 & 1.78 & 2.02 & 1.59 & 5.39 \\
\hline 19 & Polyalthia hypoleuca & Annonaceae & 15 & 15 & 0.087 & 2.23 & 2.53 & 0.61 & 5.37 \\
\hline 20 & Polyalthia sumatrana & Annonaceae & 15 & 13 & 0.118 & 2.23 & 2.19 & 0.83 & 5.25 \\
\hline
\end{tabular}




\begin{tabular}{|c|c|c|c|c|c|c|c|c|c|}
\hline 21 & Psydrax nitidum & Rubiaceae & 14 & 13 & 0.136 & 2.08 & 2.19 & 0.96 & 5.23 \\
\hline 22 & Medusanthera gracilis & Icacinaceae & 11 & 8 & 0.233 & 1.63 & 1.35 & 1.64 & 4.62 \\
\hline 23 & Memecylon dichotomum var & Melastomataceae & 15 & 7 & 0.155 & 2.23 & 1.18 & 1.09 & 4.50 \\
\hline 24 & Maclurodendron porteri & Rutaceae & 8 & 8 & 0.235 & 1.19 & 1.35 & 1.65 & 4.19 \\
\hline 25 & Diospyros lanceifolia & Ebenaceae & 13 & 10 & 0.073 & 1.93 & 1.69 & 0.51 & 4.13 \\
\hline 26 & Cinnamomum sintoc & Lauraceae & 9 & 8 & 0.202 & 1.34 & 1.35 & 1.42 & 4.11 \\
\hline 27 & Trema orientalis & Ulmaceae & 15 & 9 & 0.040 & 2.23 & 1.52 & 0.28 & 4.02 \\
\hline 28 & Sindora coriacea & Leguminosae & 5 & 5 & 0.257 & 0.74 & 0.84 & 1.81 & 3.39 \\
\hline 29 & Scaphium macropodum & Sterculiaceae & 9 & 9 & 0.076 & 1.34 & 1.52 & 0.53 & 3.39 \\
\hline 30 & Urophyllum glabrum & Rubiaceae & 10 & 8 & 0.043 & 1.48 & 1.35 & 0.30 & 3.14 \\
\hline 31 & Ptenandra echinata & Melastomataceae & 6 & 6 & 0.138 & 0.89 & 1.01 & 0.97 & 2.87 \\
\hline 32 & Diospyros buxifolia & Ebenaceae & 7 & 6 & 0.112 & 1.04 & 1.01 & 0.79 & 2.84 \\
\hline 33 & Agrostistachys longifolia var & Euphorbiaceae & 8 & 8 & 0.040 & 1.19 & 1.35 & 0.28 & 2.82 \\
\hline 34 & Macaranga gigantea & Euphorbiaceae & 7 & 6 & 0.105 & 1.04 & 1.01 & 0.74 & 2.79 \\
\hline 35 & Baccaurea brevipes & Euphorbiaceae & 7 & 6 & 0.097 & 1.04 & 1.01 & 0.69 & 2.74 \\
\hline 36 & Pittosporum ferrugineum & Pittosporaceae & 7 & 5 & 0.095 & 1.04 & 0.84 & 0.67 & 2.55 \\
\hline 37 & Ardisia crenata & Myrsinaceae & 7 & 7 & 0.046 & 1.04 & 1.18 & 0.32 & 2.54 \\
\hline 38 & Litsea elliptica & Lauraceae & 5 & 5 & 0.122 & 0.74 & 0.84 & 0.86 & 2.44 \\
\hline 39 & Sandoricum koetjape & Meliaceae & 5 & 5 & 0.096 & 0.74 & 0.84 & 0.68 & 2.26 \\
\hline 40 & Eurycoma longifolia & Simaroubaceae & 7 & 6 & 0.026 & 1.04 & 1.01 & 0.18 & 2.23 \\
\hline 41 & Fagraea fragrans & Loganiaceae & 5 & 4 & 0.099 & 0.74 & 0.67 & 0.70 & 2.11 \\
\hline 42 & Pentaspadon motleyi & Anacardiaceae & 5 & 5 & 0.074 & 0.74 & 0.84 & 0.52 & 2.11 \\
\hline 43 & Ixonanthes icosandra & Ixonanthaceae & 4 & 4 & 0.110 & 0.59 & 0.67 & 0.77 & 2.04 \\
\hline 44 & Agelaea macrophylla & Connaraceae & 3 & 3 & 0.149 & 0.45 & 0.51 & 1.05 & 2.00 \\
\hline 45 & Carallia brachiata & Rhizophoraceae & 5 & 5 & 0.046 & 0.74 & 0.84 & 0.32 & 1.91 \\
\hline 46 & Barringtonia scortechinii & Lcythidaceae & 6 & 5 & 0.022 & 0.89 & 0.84 & 0.15 & 1.89 \\
\hline 47 & Bouea macrophylla & Anacardiaceae & 3 & 3 & 0.126 & 0.45 & 0.51 & 0.89 & 1.84 \\
\hline 48 & Macaranga triloba & Euphorbiaceae & 4 & 4 & 0.072 & 0.59 & 0.67 & 0.51 & 1.77 \\
\hline 49 & Syzygium polyanthum & Myrtaceae & 4 & 4 & 0.065 & 0.59 & 0.67 & 0.46 & 1.73 \\
\hline 50 & Lepisanthes tetraphylla & Sapindaceae & 5 & 5 & 0.016 & 0.74 & 0.84 & 0.11 & 1.70 \\
\hline 51 & Parkia speciosa & Leguminosae & 1 & 1 & 0.186 & 0.15 & 0.17 & 1.31 & 1.63 \\
\hline 52 & Breynia discigera & Euphorbiaceae & 4 & 4 & 0.025 & 0.59 & 0.67 & 0.18 & 1.45 \\
\hline 53 & Ctenolophon parvifolius & Ctenolophonaceae & 1 & 4 & 0.088 & 0.15 & 0.67 & 0.62 & 1.44 \\
\hline 54 & Intsia palembanica & Leguminosae & 2 & 2 & 0.113 & 0.30 & 0.34 & 0.79 & 1.43 \\
\hline 55 & Pternandra coerulescens & Melastomataceae & 3 & 3 & 0.060 & 0.45 & 0.51 & 0.43 & 1.38 \\
\hline 56 & Calophyllum wallichianum & Guttiferae & 3 & 3 & 0.060 & 0.45 & 0.51 & 0.42 & 1.37 \\
\hline 57 & Rourea rugosa & Connaraceae & 4 & 4 & 0.012 & 0.59 & 0.67 & 0.08 & 1.35 \\
\hline 58 & Macaranga hypoleuca & Euphorbiaceae & 3 & 3 & 0.036 & 0.45 & 0.51 & 0.26 & 1.21 \\
\hline 59 & Garcinia nigrolineata & Guttiferae & 3 & 3 & 0.027 & 0.45 & 0.51 & 0.19 & 1.14 \\
\hline 60 & Elaeocarpus nitidus & Elaeocarpaceae & 3 & 3 & 0.022 & 0.45 & 0.51 & 0.16 & 1.11 \\
\hline 61 & Prunus arborea var arborea & Rosaceae & 3 & 3 & 0.020 & 0.45 & 0.51 & 0.14 & 1.09 \\
\hline 62 & Dryobalanops aromatica & Dipterocarpaceae & 1 & 1 & 0.106 & 0.15 & 0.17 & 0.74 & 1.06 \\
\hline 63 & Diospyros sumatrana & Ebenaceae & 3 & 3 & 0.015 & 0.45 & 0.51 & 0.11 & 1.06 \\
\hline 64 & Litsea grandis & Lauraceae & 2 & 2 & 0.057 & 0.30 & 0.34 & 0.40 & 1.03 \\
\hline 65 & Dissochaeta celebica & Melastomataceae & 3 & 3 & 0.010 & 0.45 & 0.51 & 0.07 & 1.02 \\
\hline 66 & Rourea mimosoides & Connaraceae & 3 & 2 & 0.023 & 0.45 & 0.34 & 0.16 & 0.95 \\
\hline 67 & Payena lucida & Sapotaceae & 2 & 2 & 0.033 & 0.30 & 0.34 & 0.23 & 0.87 \\
\hline
\end{tabular}




\begin{tabular}{|c|c|c|c|c|c|c|c|c|c|}
\hline 68 & Pyrenaria acuminata & Theaceae & 2 & 2 & 0.016 & 0.30 & 0.34 & 0.12 & 0.75 \\
\hline 69 & Cratoxylum formosum & Guttiferae & 2 & 2 & 0.012 & 0.30 & 0.34 & 0.08 & 0.72 \\
\hline 70 & Microcos latifolia & Tiliaceae & 2 & 2 & 0.010 & 0.30 & 0.34 & 0.07 & 0.70 \\
\hline 71 & Santiria griffithii & Burseraceae & 2 & 2 & 0.009 & 0.30 & 0.34 & 0.06 & 0.69 \\
\hline 72 & Pimelodendron griffithianum & Euphorbiaceae & 2 & 2 & 0.008 & 0.30 & 0.34 & 0.06 & 0.69 \\
\hline 73 & Diospyros latisepala & Ebenaceae & 2 & 2 & 0.006 & 0.30 & 0.34 & 0.04 & 0.68 \\
\hline 74 & Peliosanthes teta & Convallariaceae & 1 & 1 & 0.045 & 0.15 & 0.17 & 0.32 & 0.63 \\
\hline 75 & Dysoxylum cauliflorum & Meliaceae & 1 & 1 & 0.033 & 0.15 & 0.17 & 0.23 & 0.55 \\
\hline 76 & Clerodendrum laevifolium & Verbenaceae & 2 & 1 & 0.010 & 0.30 & 0.17 & 0.07 & 0.54 \\
\hline 77 & Friesodielsia affinis & Annonaceae & 2 & 1 & 0.009 & 0.30 & 0.17 & 0.07 & 0.53 \\
\hline 78 & Pometia pinnata & Sapindaceae & 2 & 1 & 0.008 & 0.30 & 0.17 & 0.06 & 0.52 \\
\hline 79 & Symplocos rubiginosa & Symplocaceae & 1 & 1 & 0.028 & 0.15 & 0.17 & 0.20 & 0.51 \\
\hline 80 & Garcinia atroviridis & Guttiferae & 1 & 1 & 0.019 & 0.15 & 0.17 & 0.13 & 0.45 \\
\hline 81 & Murraya paniculata & Rutaceae & 1 & 1 & 0.015 & 0.15 & 0.17 & 0.11 & 0.42 \\
\hline 82 & Schima wallichii & Theaceae & 1 & 1 & 0.014 & 0.15 & 0.17 & 0.10 & 0.41 \\
\hline 83 & Uvaria grandiflora & Annonaceae & 1 & 1 & 0.012 & 0.15 & 0.17 & 0.08 & 0.40 \\
\hline 84 & Campylospermum serratum & Ochnaceae & 1 & 1 & 0.012 & 0.15 & 0.17 & 0.08 & 0.40 \\
\hline 85 & Styrax benzoin & Styracaceae & 1 & 1 & 0.010 & 0.15 & 0.17 & 0.07 & 0.39 \\
\hline 86 & Albizzia splendens & Leguminosae & 1 & 1 & 0.008 & 0.15 & 0.17 & 0.05 & 0.37 \\
\hline 87 & Entada rheedei & Leguminosae & 1 & 1 & 0.007 & 0.15 & 0.17 & 0.05 & 0.36 \\
\hline 88 & Leptonychia caudata & Sterculiaceae & 1 & 1 & 0.007 & 0.15 & 0.17 & 0.05 & 0.36 \\
\hline 89 & Porterandia scortechchinii & Rubiaceae & 1 & 1 & 0.006 & 0.15 & 0.17 & 0.04 & 0.36 \\
\hline 90 & Maesa ramentacea & Myrsinaceae & 1 & 1 & 0.006 & 0.15 & 0.17 & 0.04 & 0.36 \\
\hline 91 & Microcos fibrocarpa & Tiliaceae & 1 & 1 & 0.005 & 0.15 & 0.17 & 0.04 & 0.35 \\
\hline 92 & Paramignya lobata & Rutaceae & 1 & 1 & 0.003 & 0.15 & 0.17 & 0.02 & 0.34 \\
\hline 93 & Calophyllum rubiginosum & Guttiferae & 1 & 1 & 0.003 & 0.15 & 0.17 & 0.02 & 0.34 \\
\hline 94 & Fibraurea tinctoria & Menispermaceae & 1 & 1 & 0.003 & 0.15 & 0.17 & 0.02 & 0.34 \\
\hline 95 & Lansium domesticum & Meliaceae & 1 & 1 & 0.003 & 0.15 & 0.17 & 0.02 & 0.34 \\
\hline 96 & Mezettia parvilora & Annonaceae & 1 & 1 & 0.003 & 0.15 & 0.17 & 0.02 & 0.34 \\
\hline 97 & Xylopia malayana var & Annonaceae & 1 & 1 & 0.002 & 0.15 & 0.17 & 0.02 & 0.33 \\
\hline 98 & Polyalthia glauca & Annonaceae & 1 & 1 & 0.002 & 0.15 & 0.17 & 0.01 & 0.33 \\
\hline 99 & Antidesma montanum & Euphorbiaceae & 1 & 1 & 0.002 & 0.15 & 0.17 & 0.01 & 0.33 \\
\hline & TOTAL & & 674 & 593 & 14.211 & 100 & 100 & 100 & 300 \\
\hline
\end{tabular}

$\mathrm{D}=$ density, $\mathrm{F}=$ frequency, $\mathrm{BA}=$ basal area, $\mathrm{RD}=$ relative density, $\mathrm{RF}=$ relative frequency, $\mathrm{RBA}=$ relative basal area, IVI = importance value index

Appendix 3. Quantitative analysis of vegetation of medicinal plants (non trees) in TTFR

\begin{tabular}{|r|l|l|c|c|r|r|r|}
\hline No. & \multicolumn{1}{|c|}{ Species } & \multicolumn{1}{c|}{ Family } & \multicolumn{1}{c|}{ D } & \multicolumn{1}{c|}{ F } & RD (\%) & RF (\%) & IVI \\
\hline 1 & Lygodium circinnatum & Schizaeaceae & 183 & 159 & 3.02 & 2.92 & 5.94 \\
\hline 2 & Globba sp. & Zingiberaceae & 147 & 140 & 2.43 & 2.57 & 4.99 \\
\hline 3 & Labisia Pumila & Myrsinaceae & 147 & 136 & 2.43 & 2.50 & 4.92 \\
\hline 4 & Tectaria singaporeana & Dryopteridaceae & 142 & 126 & 2.34 & 2.31 & 4.66 \\
\hline 5 & Croton argyratus & Euphorbiaceae & 126 & 105 & 2.08 & 1.93 & 4.01 \\
\hline 6 & Fibraurea tinctoria & Menispermaceae & 116 & 106 & 1.91 & 1.94 & 3.86 \\
\hline 7 & Melastoma malabathricum & Melastomataceae & 122 & 100 & 2.01 & 1.83 & 3.85 \\
\hline
\end{tabular}




\begin{tabular}{|c|c|c|c|c|c|c|c|}
\hline 8 & Pinanga disticha & Palmae & 117 & 100 & 1.93 & 1.83 & 3.77 \\
\hline 9 & Rourea rugosa & Connaraceae & 115 & 100 & 1.90 & 1.83 & 3.73 \\
\hline 10 & Ziziphus kunstleri & Rhamnaceae & 115 & 94 & 1.90 & 1.72 & 3.62 \\
\hline 11 & Shorea leprosula & Dipterocarpaceae & 110 & 92 & 1.82 & 1.69 & 3.50 \\
\hline 12 & Garcinia scortechinii & Guttiferae & 106 & 93 & 1.75 & 1.71 & 3.46 \\
\hline 13 & Trema orientalis & Ulmaceae & 95 & 84 & 1.57 & 1.54 & 3.11 \\
\hline 14 & Henckelia platypus & Gesneriaceae & 96 & 77 & 1.58 & 1.41 & 3.00 \\
\hline 15 & Tetracera scandens & Dilleniaceae & 97 & 75 & 1.60 & 1.38 & 2.98 \\
\hline 16 & Scaphium macropodum & Sterculiaceae & 87 & 81 & 1.44 & 1.49 & 2.92 \\
\hline 17 & Uncaria cordata & Rubiaceae & 88 & 74 & 1.45 & 1.36 & 2.81 \\
\hline 18 & Macaranga triloba & Euphorbiaceae & 83 & 77 & 1.37 & 1.41 & 2.78 \\
\hline 19 & Baccaurea parviflora & Euphorbiaceae & 80 & 74 & 1.32 & 1.36 & 2.68 \\
\hline 20 & Breynia discigera & Euphorbiaceae & 83 & 68 & 1.37 & 1.25 & 2.62 \\
\hline 21 & Lasianthus oblongus & Rubiaceae & 79 & 65 & 1.30 & 1.19 & 2.50 \\
\hline 22 & Mapania palustris & Cyperaceae & 74 & 68 & 1.22 & 1.25 & 2.47 \\
\hline 23 & Homalomena sp. & Araceae & 75 & 66 & 1.24 & 1.21 & 2.45 \\
\hline 24 & Urophyllum glabrum & Rubiaceae & 72 & 67 & 1.19 & 1.23 & 2.42 \\
\hline 25 & Dissochaeta celebica & Melastomataceae & 77 & 62 & 1.27 & 1.14 & 2.41 \\
\hline 26 & Rhodamnia cineria & Myrtaceae & 72 & 65 & 1.19 & 1.19 & 2.38 \\
\hline 27 & Smilax megacarpa & Smilacaceae & 75 & 59 & 1.24 & 1.08 & 2.32 \\
\hline 28 & Macaranga gigantea & Euphorbiaceae & 65 & 62 & 1.07 & 1.14 & 2.21 \\
\hline 29 & Mesua ferrae & Guttiferae & 64 & 60 & 1.06 & 1.10 & 2.16 \\
\hline 30 & Spatholobus ferrugineus & Leguminosae & 61 & 55 & 1.01 & 1.01 & 2.02 \\
\hline 31 & Macaranga hypoleuca & Euphorbiaceae & 67 & 49 & 1.11 & 0.90 & 2.00 \\
\hline 32 & Peperomia sp. & Piperaceae & 64 & 50 & 1.06 & 0.92 & 1.97 \\
\hline 33 & Polyalthia hypoleuca & Annonaceae & 55 & 54 & 0.91 & 0.99 & 1.90 \\
\hline 34 & Combretum sundaicum & Combretaceae & 56 & 53 & 0.92 & 0.97 & 1.90 \\
\hline 35 & Cinnamomum porrectum & Lauraceae & 56 & 50 & 0.92 & 0.92 & 1.84 \\
\hline 36 & Eurycoma longifolia & Simaroubaceae & 52 & 50 & 0.86 & 0.92 & 1.78 \\
\hline 37 & Scaphium linearicarpum & Sterculiaceae & 49 & 47 & 0.81 & 0.86 & 1.67 \\
\hline 38 & Diospyros buxifolia & Ebenaceae & 49 & 41 & 0.81 & 0.75 & 1.56 \\
\hline 39 & Embelia ribes & Myrsinaceae & 46 & 38 & 0.76 & 0.70 & 1.46 \\
\hline 40 & Goniothalamus macrophyllus & Annonaceae & 43 & 40 & 0.71 & 0.73 & 1.44 \\
\hline 41 & Taenitis blechnoides & Adiantaceae & 42 & 40 & 0.69 & 0.73 & 1.43 \\
\hline 42 & Dalbergia pinnata & Leguminosae & 42 & 40 & 0.69 & 0.73 & 1.43 \\
\hline 43 & Arenga pinnata & Palmae & 42 & 40 & 0.69 & 0.73 & 1.43 \\
\hline 44 & Lepisanthes tetraphylla & Sapindaceae & 45 & 37 & 0.74 & 0.68 & 1.42 \\
\hline 45 & Gnetum tenuifolium & Gnetaceae & 40 & 39 & 0.66 & 0.72 & 1.38 \\
\hline 46 & Ventilago sp. & Rhamnaceae & 41 & 38 & 0.68 & 0.70 & 1.37 \\
\hline 47 & Cyrtandromoea grandis & Scrophulariaceae & 40 & 38 & 0.66 & 0.70 & 1.36 \\
\hline 48 & Pternandra echinata & Melastomataceae & 41 & 36 & 0.68 & 0.66 & 1.34 \\
\hline 49 & Piper sarmentosum & Piperaceae & 38 & 36 & 0.63 & 0.66 & 1.29 \\
\hline 50 & Ochanostachys amentacea & Olacaceae & 37 & 36 & 0.61 & 0.66 & 1.27 \\
\hline 51 & Alpinia malaccensis & Zingiberaceae & 40 & 33 & 0.66 & 0.61 & 1.27 \\
\hline 52 & Agrostistachys longifolia var leptostachys & Euphorbiaceae & 37 & 32 & 0.61 & 0.59 & 1.20 \\
\hline 53 & Memecylon minutiflorum & Melastomataceae & 34 & 31 & 0.56 & 0.57 & 1.13 \\
\hline 54 & Flacourtia rukam & Flacourtiaceae & 32 & 31 & 0.53 & 0.57 & 1.10 \\
\hline
\end{tabular}




\begin{tabular}{|c|c|c|c|c|c|c|c|}
\hline 55 & Uvaria grandiflora & Annonaceae & 33 & 30 & 0.54 & 0.55 & 1.10 \\
\hline 56 & Sapium baccatum & Euphorbiaceae & 31 & 31 & 0.51 & 0.57 & 1.08 \\
\hline 57 & Porterandia anisophyllea & Rubiaceae & 31 & 30 & 0.51 & 0.55 & 1.06 \\
\hline 58 & Mussaenda sp. & Rubiaceae & 32 & 29 & 0.53 & 0.53 & 1.06 \\
\hline 59 & Blechnum orientale & Blechnaceae & 31 & 29 & 0.51 & 0.53 & 1.04 \\
\hline 60 & Hydnocarpus castanea & Flacourtiaceae & 31 & 29 & 0.51 & 0.53 & 1.04 \\
\hline 61 & Zingiber officinale & Zingiberaceae & 31 & 29 & 0.51 & 0.53 & 1.04 \\
\hline 62 & Cyathea mollucana & Cyatheaceae & 31 & 28 & 0.51 & 0.51 & 1.03 \\
\hline 63 & Goniothalamus malayanus & Annonaceae & 29 & 29 & 0.48 & 0.53 & 1.01 \\
\hline 64 & Donax grandis & Marantaceae & 30 & 28 & 0.50 & 0.51 & 1.01 \\
\hline 65 & Leptonychia caudata & Sterculiaceae & 31 & 27 & 0.51 & 0.50 & 1.01 \\
\hline 66 & Zingiber griffithii & Zingiberaceae & 31 & 27 & 0.51 & 0.50 & 1.01 \\
\hline 67 & Macaranga conifera & Euphorbiaceae & 32 & 26 & 0.53 & 0.48 & 1.01 \\
\hline 68 & Rourea acutipetala ssp. acutipetala & Connaraceae & 30 & 27 & 0.50 & 0.50 & 0.99 \\
\hline 69 & Xanthophyllum amoenum & Polygalaceae & 30 & 27 & 0.50 & 0.50 & 0.99 \\
\hline 70 & Barringtonia scortechinii & Lecythidaceae & 28 & 28 & 0.46 & 0.51 & 0.98 \\
\hline 71 & Antidesma montanum & Euphorbiaceae & 31 & 25 & 0.51 & 0.46 & 0.97 \\
\hline 72 & Lycopodiella cernua & Lycopodiaceae & 28 & 27 & 0.46 & 0.50 & 0.96 \\
\hline 73 & Dissochaeta intermedia & Melastomataceae & 28 & 27 & 0.46 & 0.50 & 0.96 \\
\hline 74 & Baccaurea brevipes & Euphorbiaceae & 27 & 26 & 0.45 & 0.48 & 0.92 \\
\hline 75 & Molineria latifolia & Hypoxidaceae & 28 & 25 & 0.46 & 0.46 & 0.92 \\
\hline 76 & Clerodendron laevifolium & Verbenaceae & 26 & 26 & 0.43 & 0.48 & 0.91 \\
\hline 77 & Rourea mimosoides & Connaraceae & 27 & 25 & 0.45 & 0.46 & 0.90 \\
\hline 78 & Ardisia crenata & Myrsinaceae & 26 & 25 & 0.43 & 0.46 & 0.89 \\
\hline 79 & Donax parviflorus & Marantaceae & 27 & 24 & 0.45 & 0.44 & 0.89 \\
\hline 80 & Xylopia ferruginea & Annonaceae & 25 & 25 & 0.41 & 0.46 & 0.87 \\
\hline 81 & Nephrolepis auriculata & Oleandraceae & 26 & 24 & 0.43 & 0.44 & 0.87 \\
\hline 82 & Selaginella wildenowii & Selaginellaceae & 27 & 23 & 0.45 & 0.42 & 0.87 \\
\hline 83 & Cinnamomum sintoc & Lauraceae & 25 & 24 & 0.41 & 0.44 & 0.85 \\
\hline 84 & Maclurodendron porteri & Rutaceae & 25 & 24 & 0.41 & 0.44 & 0.85 \\
\hline 85 & Campylospermum serratum & Ochnaceae & 24 & 24 & 0.40 & 0.44 & 0.84 \\
\hline 86 & Amischotolype griffithii & Commelinaceae & 26 & 22 & 0.43 & 0.40 & 0.83 \\
\hline 87 & Friesodielsia affinis & Annonaceae & 25 & 22 & 0.41 & 0.40 & 0.82 \\
\hline 88 & Prunus arborea var arborea & Rosaceae & 23 & 23 & 0.38 & 0.42 & 0.80 \\
\hline 89 & Smilex sp. & Smilacaceae & 23 & 22 & 0.38 & 0.40 & 0.78 \\
\hline 90 & Fissistigma lanuginosum & Annonaceae & 22 & 22 & 0.36 & 0.40 & 0.77 \\
\hline 91 & Elaeocarpus floribundus & Elaeocarpaceae & 23 & 20 & 0.38 & 0.37 & 0.75 \\
\hline 92 & Polyalthia sumatrana & Annonaceae & 21 & 21 & 0.35 & 0.39 & 0.73 \\
\hline 93 & Spatholobus bornensis & Leguminosae & 21 & 21 & 0.35 & 0.39 & 0.73 \\
\hline 94 & Zingiber spectabile & Zingiberaceae & 21 & 21 & 0.35 & 0.39 & 0.73 \\
\hline 95 & Tetracera indica & Dilleniaceae & 20 & 20 & 0.33 & 0.37 & 0.70 \\
\hline 96 & Polyalthia glauca & Annonaceae & 20 & 19 & 0.33 & 0.35 & 0.68 \\
\hline 97 & Costus speciocus & Costaceae & 20 & 18 & 0.33 & 0.33 & 0.66 \\
\hline 98 & Garcinia nigrolineata & Guttiferae & 19 & 17 & 0.31 & 0.31 & 0.63 \\
\hline 99 & Epipremnum giganteum & Araceae & 20 & 16 & 0.33 & 0.29 & 0.62 \\
\hline 100 & Sindora coriacea & Leguminosae & 18 & 17 & 0.30 & 0.31 & 0.61 \\
\hline 101 & Mitrella kentii & Annonaceae & 19 & 16 & 0.31 & 0.29 & 0.61 \\
\hline
\end{tabular}




\begin{tabular}{|c|c|c|c|c|c|c|c|}
\hline 102 & Calophyllum wallichianum & Guttiferae & 18 & 16 & 0.30 & 0.29 & 0.59 \\
\hline 103 & Cratoxylum formosum & Guttiferae & 18 & 16 & 0.30 & 0.29 & 0.59 \\
\hline 104 & Galearia fulva & Pandaceae & 16 & 16 & 0.26 & 0.29 & 0.56 \\
\hline 105 & Gironniera hirta & Ulmaceae & 16 & 15 & 0.26 & 0.28 & 0.54 \\
\hline 106 & Cinnamomum javanicum & Lauraceae & 15 & 15 & 0.25 & 0.28 & 0.52 \\
\hline 107 & Diospyros sumatrana & Ebenaceae & 15 & 14 & 0.25 & 0.26 & 0.50 \\
\hline 108 & Agelaea macrophylla & Connaraceae & 14 & 14 & 0.23 & 0.26 & 0.49 \\
\hline 109 & Maesa ramentacea & Myrsinaceae & 14 & 14 & 0.23 & 0.26 & 0.49 \\
\hline 110 & Coscinium fenestratum & Menispermaceae & 15 & 13 & 0.25 & 0.24 & 0.49 \\
\hline 111 & Thottea corymbosa & Aristolochiaceae & 14 & 13 & 0.23 & 0.24 & 0.47 \\
\hline 112 & Medusanthera gracilis & Icacinaceae & 14 & 13 & 0.23 & 0.24 & 0.47 \\
\hline 113 & Epiprinus malayanus & Euphorbiaceae & 13 & 13 & 0.21 & 0.24 & 0.45 \\
\hline 114 & Mallotus macrostachys & Euphorbiaceae & 13 & 13 & 0.21 & 0.24 & 0.45 \\
\hline 115 & Hanguana malayana & Hanguanaceae & 13 & 13 & 0.21 & 0.24 & 0.45 \\
\hline 116 & Litsea elliptica & Lauraceae & 13 & 13 & 0.21 & 0.24 & 0.45 \\
\hline 117 & Ixonanthes icosandra & Ixonanthaceae & 13 & 12 & 0.21 & 0.22 & 0.43 \\
\hline 118 & Diospyros argenteum & Ebenaceae & 12 & 12 & 0.20 & 0.22 & 0.42 \\
\hline 119 & Gnetum gnemon & Gnetaceae & 12 & 12 & 0.20 & 0.22 & 0.42 \\
\hline 120 & Ximenia americana & Olacaceae & 12 & 11 & 0.20 & 0.20 & 0.40 \\
\hline 121 & Selaginella plana & Selaginellaceae & 12 & 11 & 0.20 & 0.20 & 0.40 \\
\hline 122 & Microcos latifolia & Tiliaceae & 12 & 11 & 0.20 & 0.20 & 0.40 \\
\hline 123 & Crytandra capulata var capulata & Gesneriaceae & 11 & 11 & 0.18 & 0.20 & 0.38 \\
\hline 124 & Bauhinia bidentata & Leguminosae & 11 & 11 & 0.18 & 0.20 & 0.38 \\
\hline 125 & Memecylon dichotomum var dichotomum & Melastomataceae & 11 & 11 & 0.18 & 0.20 & 0.38 \\
\hline 126 & Hullettia dumosa & Moraceae & 11 & 11 & 0.18 & 0.20 & 0.38 \\
\hline 127 & Leea indica & Leeaceae & 12 & 10 & 0.20 & 0.18 & 0.38 \\
\hline 128 & Pimelodendron griffithianum & Euphorbiaceae & 11 & 10 & 0.18 & 0.18 & 0.37 \\
\hline 129 & Luvunga scandens & Rutaceae & 11 & 10 & 0.18 & 0.18 & 0.37 \\
\hline 130 & Artabotrys grandifolius & Annonaceae & 10 & 10 & 0.17 & 0.18 & 0.35 \\
\hline 131 & Sticherus truncatus & Gleicheniaceae & 10 & 10 & 0.17 & 0.18 & 0.35 \\
\hline 132 & Pentaspadon motleyi & Anacardiaceae & 9 & 9 & 0.15 & 0.17 & 0.31 \\
\hline 133 & Ctenolophon parvifolius & Ctenolophonaceae & 9 & 9 & 0.15 & 0.17 & 0.31 \\
\hline 134 & Sandoricum koetjape & Meliaceae & 9 & 9 & 0.15 & 0.17 & 0.31 \\
\hline 135 & Coptosapelta griffithii & Rubiaceae & 9 & 9 & 0.15 & 0.17 & 0.31 \\
\hline 136 & Poikilospermum sp. & Cecropiaceae & 10 & 8 & 0.17 & 0.15 & 0.31 \\
\hline 137 & Chrysophyllum roxburghii & Sapotaceae & 10 & 8 & 0.17 & 0.15 & 0.31 \\
\hline 138 & Diospyros lanceifolia & Ebenaceae & 9 & 8 & 0.15 & 0.15 & 0.30 \\
\hline 139 & Salacia grandiflora & Celastraceae & 8 & 8 & 0.13 & 0.15 & 0.28 \\
\hline 140 & Tacca integrifolia & Taccaceae & 8 & 8 & 0.13 & 0.15 & 0.28 \\
\hline 141 & Callicarpa candicans & Verbenaceae & 8 & 8 & 0.13 & 0.15 & 0.28 \\
\hline 142 & Dysoxylum cauliflorum & Meliaceae & 8 & 7 & 0.13 & 0.13 & 0.26 \\
\hline 143 & Santiria griffithii & Burseraceae & 7 & 7 & 0.12 & 0.13 & 0.24 \\
\hline 144 & Litsea grandis & Lauraceae & 7 & 7 & 0.12 & 0.13 & 0.24 \\
\hline 145 & Psydrax nitidum & Rubiaceae & 7 & 7 & 0.12 & 0.13 & 0.24 \\
\hline 146 & Cayratia molissima & Vitaceae & 7 & 7 & 0.12 & 0.13 & 0.24 \\
\hline 147 & Lepidagathis sp. & Acanthaceae & 7 & 6 & 0.12 & 0.11 & 0.23 \\
\hline 148 & Acrotrema costatum & Dilleniaceae & 7 & 6 & 0.12 & 0.11 & 0.23 \\
\hline
\end{tabular}




\begin{tabular}{|c|c|c|c|c|c|c|c|}
\hline 149 & Molineria capitulata & Hypoxidaceae & 7 & 6 & 0.12 & 0.11 & 0.23 \\
\hline 150 & Bouea macrophylla & Anacardiaceae & 6 & 6 & 0.10 & 0.11 & 0.21 \\
\hline 151 & Desmos chinensis & Annonaceae & 6 & 6 & 0.10 & 0.11 & 0.21 \\
\hline 152 & Erycibe albida & Convolvulaceae & 6 & 6 & 0.10 & 0.11 & 0.21 \\
\hline 153 & Intsia palembanica & Leguminosae & 6 & 6 & 0.10 & 0.11 & 0.21 \\
\hline 154 & Clidemia hirta & Melastomataceae & 6 & 6 & 0.10 & 0.11 & 0.21 \\
\hline 155 & Lansium domesticum & Meliaceae & 6 & 6 & 0.10 & 0.11 & 0.21 \\
\hline 156 & Ardisia villosa & Myrsinaceae & 6 & 6 & 0.10 & 0.11 & 0.21 \\
\hline 157 & Pittosporum ferrugineum & Pittosporaceae & 6 & 6 & 0.10 & 0.11 & 0.21 \\
\hline 158 & Peliosanthes teta & Convallariaceae & 6 & 5 & 0.10 & 0.09 & 0.19 \\
\hline 159 & Pyrenaria acuminata & Theaceae & 6 & 5 & 0.10 & 0.09 & 0.19 \\
\hline 160 & Syngramma alismifolia & Adiantaceae & 5 & 5 & 0.08 & 0.09 & 0.17 \\
\hline 161 & Pyramidanthe prismatica & Annonaceae & 5 & 5 & 0.08 & 0.09 & 0.17 \\
\hline 162 & Thottea tomentosa & Aristolochiaceae & 5 & 5 & 0.08 & 0.09 & 0.17 \\
\hline 163 & Phyllanthus emblica & Euphorbiaceae & 5 & 5 & 0.08 & 0.09 & 0.17 \\
\hline 164 & Carallia brachiata & Rhizophoraceae & 5 & 5 & 0.08 & 0.09 & 0.17 \\
\hline 165 & Coptosapelta parviflora & Rubiaceae & 5 & 5 & 0.08 & 0.09 & 0.17 \\
\hline 166 & Selaginella wallichii & Selaginellaceae & 5 & 5 & 0.08 & 0.09 & 0.17 \\
\hline 167 & Parkia speciosa & Leguminosae & 5 & 4 & 0.08 & 0.07 & 0.16 \\
\hline 168 & Hoya sp. & Asclepiadaceae & 4 & 4 & 0.07 & 0.07 & 0.14 \\
\hline 169 & Asplenium nidus & Aspleniaceae & 4 & 4 & 0.07 & 0.07 & 0.14 \\
\hline 170 & Amischotolype molissima & Commelinaceae & 4 & 4 & 0.07 & 0.07 & 0.14 \\
\hline 171 & Cyrtandra capulata var capulata & Gesneriaceae & 4 & 4 & 0.07 & 0.07 & 0.14 \\
\hline 172 & Toona sp. & Meliaceae & 4 & 4 & 0.07 & 0.07 & 0.14 \\
\hline 173 & Chassalia chartacea & Rubiaceae & 4 & 4 & 0.07 & 0.07 & 0.14 \\
\hline 174 & Pometia pinnata & Sapindaceae & 4 & 4 & 0.07 & 0.07 & 0.14 \\
\hline 175 & Clerodendron deflexum & Verbenaceae & 4 & 4 & 0.07 & 0.07 & 0.14 \\
\hline 176 & Ancistrocladus tectorius & Ancistrocladaceae & 3 & 3 & 0.05 & 0.06 & 0.10 \\
\hline 177 & Popowia tomentosa & Annonaceae & 3 & 3 & 0.05 & 0.06 & 0.10 \\
\hline 178 & Colocasia esculenta & Araceae & 3 & 3 & 0.05 & 0.06 & 0.10 \\
\hline 179 & Forrestia griffithii & Commelinaceae & 3 & 3 & 0.05 & 0.06 & 0.10 \\
\hline 180 & Cratoxylum cochinchinense & Guttiferae & 3 & 3 & 0.05 & 0.06 & 0.10 \\
\hline 181 & Litsea lancifolia var lancifolia & Lauraceae & 3 & 3 & 0.05 & 0.06 & 0.10 \\
\hline 182 & Oncosperma horridum & Palmae & 3 & 3 & 0.05 & 0.06 & 0.10 \\
\hline 183 & Salacca glabrescens & Palmae & 3 & 3 & 0.05 & 0.06 & 0.10 \\
\hline 184 & Payena lucida & Sapotaceae & 3 & 3 & 0.05 & 0.06 & 0.10 \\
\hline 185 & Selaginella intermedia & Selaginellaceae & 3 & 3 & 0.05 & 0.06 & 0.10 \\
\hline 186 & Styrax benzoin & Styracaceae & 3 & 3 & 0.05 & 0.06 & 0.10 \\
\hline 187 & Symplocos rubiginosa & Symplocaceae & 3 & 3 & 0.05 & 0.06 & 0.10 \\
\hline 188 & Diospyros latisepala & Ebenaceae & 3 & 2 & 0.05 & 0.04 & 0.09 \\
\hline 189 & Garcinia atroviridis & Guttiferae & 3 & 2 & 0.05 & 0.04 & 0.09 \\
\hline 190 & Paramignya lobata & Rutaceae & 3 & 2 & 0.05 & 0.04 & 0.09 \\
\hline 191 & Mezettia leptopoda & Annonaceae & 2 & 2 & 0.03 & 0.04 & 0.07 \\
\hline 192 & Alstonia augustiloba & Apocynaceae & 2 & 2 & 0.03 & 0.04 & 0.07 \\
\hline 193 & Aralidium pinnatifitidum & Aralidiaceae & 2 & 2 & 0.03 & 0.04 & 0.07 \\
\hline 194 & Connarus ferrugineus & Connaraceae & 2 & 2 & 0.03 & 0.04 & 0.07 \\
\hline 195 & Dipteris conjugata & Dipteridaceae & 2 & 2 & 0.03 & 0.04 & 0.07 \\
\hline
\end{tabular}




\begin{tabular}{|c|c|c|c|c|c|c|c|}
\hline 196 & Garcinia griffithii & Guttiferae & 2 & 2 & 0.03 & 0.04 & 0.07 \\
\hline 197 & Fagraea fragrans & Loganiaceae & 2 & 2 & 0.03 & 0.04 & 0.07 \\
\hline 198 & Fagraea racemosa & Loganiaceae & 2 & 2 & 0.03 & 0.04 & 0.07 \\
\hline 199 & Pternandra coerulescens & Melastomataceae & 2 & 2 & 0.03 & 0.04 & 0.07 \\
\hline 200 & Artocarpus elasticus & Moraceae & 2 & 2 & 0.03 & 0.04 & 0.07 \\
\hline 201 & Pinanga pumila & Palmae & 2 & 2 & 0.03 & 0.04 & 0.07 \\
\hline 202 & Podocarpus polystachyus & Podocarpaceae & 2 & 2 & 0.03 & 0.04 & 0.07 \\
\hline 203 & Pteris ensiformis & Pteridaceae & 2 & 2 & 0.03 & 0.04 & 0.07 \\
\hline 204 & Carallia suffruticosa & Rhizophoraceae & 2 & 2 & 0.03 & 0.04 & 0.07 \\
\hline 205 & Schima wallichii & Theaceae & 2 & 2 & 0.03 & 0.04 & 0.07 \\
\hline 206 & Globba patens & Zingiberaceae & 2 & 2 & 0.03 & 0.04 & 0.07 \\
\hline 207 & Xylopia malayana var obscura & Annonaceae & 1 & 1 & 0.02 & 0.02 & 0.03 \\
\hline 208 & Cnestis palala & Connaraceae & 1 & 1 & 0.02 & 0.02 & 0.03 \\
\hline 209 & Merremia peltata & Convolvulaceae & 1 & 1 & 0.02 & 0.02 & 0.03 \\
\hline 210 & Pleocnemia irregularis & Dryopteridaceae & 1 & 1 & 0.02 & 0.02 & 0.03 \\
\hline 211 & Bridelia tomentosa & Euphorbiaceae & 1 & 1 & 0.02 & 0.02 & 0.03 \\
\hline 212 & Croton laevifolium & Euphorbiaceae & 1 & 1 & 0.02 & 0.02 & 0.03 \\
\hline 213 & Sauropus androgynus & Euphorbiaceae & 1 & 1 & 0.02 & 0.02 & 0.03 \\
\hline 214 & Didissandra wrayi & Gesneriaceae & 1 & 1 & 0.02 & 0.02 & 0.03 \\
\hline 215 & Ixonanthes reticulata & Ixonanthaceae & 1 & 1 & 0.02 & 0.02 & 0.03 \\
\hline 216 & Saraca cauliflora & Leguminosae & 1 & 1 & 0.02 & 0.02 & 0.03 \\
\hline 217 & Sindora wallichii & Leguminosae & 1 & 1 & 0.02 & 0.02 & 0.03 \\
\hline 218 & Fagraea acuminatissima & Loganiaceae & 1 & 1 & 0.02 & 0.02 & 0.03 \\
\hline 219 & Tinomiscium petiolare & Menispermaceae & 1 & 1 & 0.02 & 0.02 & 0.03 \\
\hline 220 & Ficus hispida & Moraceae & 1 & 1 & 0.02 & 0.02 & 0.03 \\
\hline 221 & Syzygium polyanthum & Myrtaceae & 1 & 1 & 0.02 & 0.02 & 0.03 \\
\hline 222 & Euthemis leucocarpa & Ochnaceae & 1 & 1 & 0.02 & 0.02 & 0.03 \\
\hline 223 & Plocoglottis javanica & Orchidaceae & 1 & 1 & 0.02 & 0.02 & 0.03 \\
\hline 224 & Gynotroches axillaris & Rhizophoraceae & 1 & 1 & 0.02 & 0.02 & 0.03 \\
\hline 225 & Fagerlindia fasciculata & Rubiaceae & 1 & 1 & 0.02 & 0.02 & 0.03 \\
\hline 226 & Symplocos crassipes var penangiana & Symplocaceae & 1 & 1 & 0.02 & 0.02 & 0.03 \\
\hline 227 & Microcos fibrocarpa & Tiliaceae & 1 & 1 & 0.02 & 0.02 & 0.03 \\
\hline \multirow[t]{2}{*}{228} & Rinorea anguifera & Violaceae & 1 & 1 & 0.02 & 0.02 & 0.03 \\
\hline & & & 6059 & 5450 & 100 & 100 & 200 \\
\hline
\end{tabular}

$\mathrm{D}=$ density, $\mathrm{F}=$ frequency, $\mathrm{RD}=$ relative density, $\mathrm{RF}=$ relative frequency, $\mathrm{IVI}=$ importance value index

Appendix 4. Quantitative analysis for Family Value Index (tree)

\begin{tabular}{|r|l|r|r|r|r|r|r|c|}
\hline & \multicolumn{1}{|c|}{ Family } & \multicolumn{1}{c|}{ D } & \multicolumn{1}{c|}{ F } & \multicolumn{1}{c|}{ BA } & RD(\%) & RF(\%) & RBA(\%) & FVI \\
\hline 1 & Lauraceae & 71 & 60 & 2.319 & 10.53 & 10.12 & 16.32 & 36.97 \\
\hline 2 & Euphorbiaceae & 104 & 85 & 0.979 & 15.43 & 14.33 & 6.89 & 36.66 \\
\hline 3 & Guttiferae & 53 & 50 & 0.999 & 7.86 & 8.43 & 7.03 & 23.32 \\
\hline 4 & Dipterocarpaceae & 22 & 19 & 1.862 & 3.26 & 3.20 & 13.10 & 19.57 \\
\hline 5 & Annonaceae & 48 & 45 & 0.459 & 7.12 & 7.59 & 3.23 & 17.94 \\
\hline 6 & Melastomataceae & 48 & 37 & 0.595 & 7.12 & 6.24 & 4.19 & 17.55 \\
\hline 7 & Olacaceae & 15 & 14 & 1.356 & 2.23 & 2.36 & 9.54 & 14.13 \\
\hline 8 & Flacourtiaceae & 24 & 23 & 0.630 & 3.56 & 3.88 & 4.43 & 11.87 \\
\hline
\end{tabular}




\begin{tabular}{|c|c|c|c|c|c|c|c|c|}
\hline 9 & Sterculiaceae & 24 & 23 & 0.506 & 3.56 & 3.88 & 3.56 & 11.00 \\
\hline 10 & Elaeocarpaceae & 26 & 25 & 0.389 & 3.86 & 4.22 & 2.74 & 10.81 \\
\hline 11 & Polygalaceae & 21 & 20 & 0.398 & 3.12 & 3.37 & 2.80 & 9.29 \\
\hline 12 & Rubiaceae & 25 & 22 & 0.185 & 3.71 & 3.71 & 1.30 & 8.72 \\
\hline 13 & Ebenaceae & 25 & 21 & 0.206 & 3.71 & 3.54 & 1.45 & 8.70 \\
\hline 14 & Myrtaceae & 22 & 17 & 0.298 & 3.26 & 2.87 & 2.10 & 8.23 \\
\hline 15 & Leguminosae & 10 & 10 & 0.570 & 1.48 & 1.69 & 4.01 & 7.18 \\
\hline 16 & Moraceae & 5 & 5 & 0.642 & 0.74 & 0.84 & 4.52 & 6.11 \\
\hline 17 & Rutaceae & 10 & 10 & 0.253 & 1.48 & 1.69 & 1.78 & 4.95 \\
\hline 18 & Icacinaceae & 11 & 8 & 0.233 & 1.63 & 1.35 & 1.64 & 4.62 \\
\hline 19 & Connaraceae & 10 & 9 & 0.184 & 1.48 & 1.52 & 1.30 & 4.30 \\
\hline 20 & Ulmaceae & 15 & 9 & 0.040 & 2.23 & 1.52 & 0.28 & 4.02 \\
\hline 21 & Anacardiaceae & 8 & 8 & 0.201 & 1.19 & 1.35 & 1.41 & 3.95 \\
\hline 22 & Meliaceae & 7 & 7 & 0.131 & 1.04 & 1.18 & 0.92 & 3.14 \\
\hline 23 & Myrsinaceae & 8 & 8 & 0.052 & 1.19 & 1.35 & 0.37 & 2.90 \\
\hline 24 & Pittosporaceae & 7 & 5 & 0.095 & 1.04 & 0.84 & 0.67 & 2.55 \\
\hline 25 & Simaroubaceae & 7 & 6 & 0.026 & 1.04 & 1.01 & 0.18 & 2.23 \\
\hline 26 & Sapindaceae & 7 & 6 & 0.024 & 1.04 & 1.01 & 0.17 & 2.22 \\
\hline 27 & Loganiaceae & 5 & 4 & 0.099 & 0.74 & 0.67 & 0.70 & 2.11 \\
\hline 28 & Ixonanthaceae & 4 & 4 & 0.110 & 0.59 & 0.67 & 0.77 & 2.04 \\
\hline 29 & Rhizophoraceae & 5 & 5 & 0.046 & 0.74 & 0.84 & 0.32 & 1.91 \\
\hline 30 & Lecythidaceae & 6 & 5 & 0.022 & 0.89 & 0.84 & 0.15 & 1.89 \\
\hline 31 & Ctenolophonaceae & 1 & 4 & 0.088 & 0.15 & 0.67 & 0.62 & 1.44 \\
\hline 32 & Theaceae & 3 & 3 & 0.030 & 0.45 & 0.51 & 0.21 & 1.16 \\
\hline 33 & Rosaceae & 3 & 3 & 0.020 & 0.45 & 0.51 & 0.14 & 1.09 \\
\hline 34 & Tiliaceae & 3 & 3 & 0.015 & 0.45 & 0.51 & 0.11 & 1.06 \\
\hline 35 & Sapotaceae & 2 & 2 & 0.033 & 0.30 & 0.34 & 0.23 & 0.87 \\
\hline 36 & Burseraceae & 2 & 2 & 0.009 & 0.30 & 0.34 & 0.06 & 0.69 \\
\hline 37 & Convallariaceae & 1 & 1 & 0.045 & 0.15 & 0.17 & 0.32 & 0.63 \\
\hline 38 & Verbenaceae & 2 & 1 & 0.010 & 0.30 & 0.17 & 0.07 & 0.54 \\
\hline 39 & Symplocaceae & 1 & 1 & 0.028 & 0.15 & 0.17 & 0.20 & 0.51 \\
\hline 40 & Ochnaceae & 1 & 1 & 0.012 & 0.15 & 0.17 & 0.08 & 0.40 \\
\hline 41 & Styracaceae & 1 & 1 & 0.010 & 0.15 & 0.17 & 0.07 & 0.39 \\
\hline \multirow[t]{2}{*}{42} & Menispermaceae & 1 & 1 & 0.003 & 0.15 & 0.17 & 0.02 & 0.34 \\
\hline & TOTAL & 674 & 593 & 14.211 & 100 & 100 & 100 & 300 \\
\hline
\end{tabular}

$\mathrm{D}=$ density, $\mathrm{F}=$ frequency, $\mathrm{RD}=$ relative density, $\mathrm{RF}=$ relative frequency, $\mathrm{FVI}=$ family value index

Appendix 5. Quantitative analysis for Family Value Index (non tree)

\begin{tabular}{|l|l|c|c|r|r|r|}
\hline & Family & D & F & RD(\%) & RF(\%) & FVI \\
\hline 1 & Euphorbiaceae & 707 & 619 & 11.67 & 11.36 & 23.03 \\
\hline 2 & Annonaceae & 319 & 305 & 5.26 & 5.60 & 10.86 \\
\hline 3 & Rubiaceae & 328 & 291 & 5.41 & 5.34 & 10.75 \\
\hline 4 & Melastomataceae & 321 & 275 & 5.30 & 5.05 & 10.34 \\
\hline 5 & Zingiberaceae & 272 & 252 & 4.49 & 4.62 & 9.11 \\
\hline 6 & Myrsinaceae & 239 & 219 & 3.94 & 4.02 & 7.96 \\
\hline 7 & Guttiferae & 233 & 209 & 3.85 & 3.83 & 7.68 \\
\hline 8 & Connaraceae & 189 & 169 & 3.12 & 3.10 & 6.22 \\
\hline
\end{tabular}




\begin{tabular}{|c|c|c|c|c|c|c|}
\hline 9 & Schizaeaceae & 183 & 159 & 3.02 & 2.92 & 5.94 \\
\hline 10 & Leguminosae & 166 & 156 & 2.74 & 2.86 & 5.60 \\
\hline 11 & Sterculiaceae & 167 & 155 & 2.76 & 2.84 & 5.60 \\
\hline 12 & Palmae & 167 & 148 & 2.76 & 2.72 & 5.47 \\
\hline 13 & Rhamnaceae & 156 & 132 & 2.57 & 2.42 & 5.00 \\
\hline 14 & Dryopteridaceae & 143 & 127 & 2.36 & 2.33 & 4.69 \\
\hline 15 & Menispermaceae & 132 & 120 & 2.18 & 2.20 & 4.38 \\
\hline 16 & Lauraceae & 119 & 112 & 1.96 & 2.06 & 4.02 \\
\hline 17 & Dilleniaceae & 124 & 101 & 2.05 & 1.85 & 3.90 \\
\hline 18 & Ulmaceae & 111 & 99 & 1.83 & 1.82 & 3.65 \\
\hline 19 & Gesneriaceae & 112 & 93 & 1.85 & 1.71 & 3.55 \\
\hline 20 & Dipterocarpaceae & 110 & 92 & 1.82 & 1.69 & 3.50 \\
\hline 21 & Piperaceae & 102 & 86 & 1.68 & 1.58 & 3.26 \\
\hline 22 & Araceae & 98 & 85 & 1.62 & 1.56 & 3.18 \\
\hline 23 & Smilacaceae & 98 & 81 & 1.62 & 1.49 & 3.10 \\
\hline 24 & Ebenaceae & 88 & 77 & 1.45 & 1.41 & 2.87 \\
\hline 25 & Cyperaceae & 74 & 68 & 1.22 & 1.25 & 2.47 \\
\hline 26 & Myrtaceae & 73 & 66 & 1.20 & 1.21 & 2.42 \\
\hline 27 & Flacourtiaceae & 63 & 60 & 1.04 & 1.10 & 2.14 \\
\hline 28 & Combretaceae & 56 & 53 & 0.92 & 0.97 & 1.90 \\
\hline 29 & Marantaceae & 57 & 52 & 0.94 & 0.95 & 1.89 \\
\hline 30 & Gnetaceae & 52 & 51 & 0.86 & 0.94 & 1.79 \\
\hline 31 & Simaroubaceae & 52 & 50 & 0.86 & 0.92 & 1.78 \\
\hline 32 & Olacaceae & 49 & 47 & 0.81 & 0.86 & 1.67 \\
\hline 33 & Adiantaceae & 47 & 45 & 0.78 & 0.83 & 1.60 \\
\hline 34 & Sapindaceae & 49 & 41 & 0.81 & 0.75 & 1.56 \\
\hline 35 & Selaginellaceae & 47 & 42 & 0.78 & 0.77 & 1.55 \\
\hline 36 & Scrophulariaceae & 40 & 38 & 0.66 & 0.70 & 1.36 \\
\hline 37 & Verbenaceae & 38 & 38 & 0.63 & 0.70 & 1.32 \\
\hline 38 & Rutaceae & 39 & 36 & 0.64 & 0.66 & 1.30 \\
\hline 39 & Hypoxidaceae & 35 & 31 & 0.58 & 0.57 & 1.15 \\
\hline 40 & Commelinaceae & 33 & 29 & 0.54 & 0.53 & 1.08 \\
\hline 41 & Blechnaceae & 31 & 29 & 0.51 & 0.53 & 1.04 \\
\hline 42 & Cyatheaceae & 31 & 28 & 0.51 & 0.51 & 1.03 \\
\hline 43 & Polygalaceae & 30 & 27 & 0.50 & 0.50 & 0.99 \\
\hline 44 & Lecythidaceae & 28 & 28 & 0.46 & 0.51 & 0.98 \\
\hline 45 & Lycopodiaceae & 28 & 27 & 0.46 & 0.50 & 0.96 \\
\hline 46 & Meliaceae & 27 & 26 & 0.45 & 0.48 & 0.92 \\
\hline 47 & Ochnaceae & 25 & 25 & 0.41 & 0.46 & 0.87 \\
\hline 48 & Oleandraceae & 26 & 24 & 0.43 & 0.44 & 0.87 \\
\hline 49 & Rosaceae & 23 & 23 & 0.38 & 0.42 & 0.80 \\
\hline 50 & Elaeocarpaceae & 23 & 20 & 0.38 & 0.37 & 0.75 \\
\hline 51 & Costaceae & 20 & 18 & 0.33 & 0.33 & 0.66 \\
\hline 52 & Aristolochiaceae & 19 & 18 & 0.31 & 0.33 & 0.64 \\
\hline 53 & Pandaceae & 16 & 16 & 0.26 & 0.29 & 0.56 \\
\hline 54 & Anacardiaceae & 15 & 15 & 0.25 & 0.28 & 0.52 \\
\hline 55 & Moraceae & 14 & 14 & 0.23 & 0.26 & 0.49 \\
\hline
\end{tabular}




\begin{tabular}{|r|l|r|r|r|r|r|}
\hline 56 & Icacinaceae & 14 & 13 & 0.23 & 0.24 & 0.47 \\
\hline 57 & Ixonanthaceae & 14 & 13 & 0.23 & 0.24 & 0.47 \\
\hline 58 & Hanguanaceae & 13 & 13 & 0.21 & 0.24 & 0.45 \\
\hline 59 & Tiliaceae & 13 & 12 & 0.21 & 0.22 & 0.43 \\
\hline 60 & Sapotaceae & 13 & 11 & 0.21 & 0.20 & 0.42 \\
\hline 61 & Leeaceae & 12 & 10 & 0.20 & 0.18 & 0.38 \\
\hline 62 & Gleicheniaceae & 10 & 10 & 0.17 & 0.18 & 0.35 \\
\hline 63 & Ctenolophonaceae & 9 & 9 & 0.15 & 0.17 & 0.31 \\
\hline 64 & Cecropiaceae & 10 & 8 & 0.17 & 0.15 & 0.31 \\
\hline 65 & Celastraceae & 8 & 8 & 0.13 & 0.15 & 0.28 \\
\hline 66 & Rhizophoraceae & 8 & 8 & 0.13 & 0.15 & 0.28 \\
\hline 67 & Taccaceae & 8 & 8 & 0.13 & 0.15 & 0.28 \\
\hline 68 & Theaceae & 8 & 7 & 0.13 & 0.13 & 0.26 \\
\hline 69 & Burseraceae & 7 & 7 & 0.12 & 0.13 & 0.24 \\
\hline 70 & Convolvulaceae & 7 & 7 & 0.12 & 0.13 & 0.24 \\
\hline 71 & Vitaceae & 7 & 7 & 0.12 & 0.13 & 0.24 \\
\hline 72 & Acanthaceae & 7 & 6 & 0.12 & 0.11 & 0.23 \\
\hline 73 & Pittosporaceae & 6 & 6 & 0.10 & 0.11 & 0.21 \\
\hline 74 & Convallariaceae & 6 & 5 & 0.10 & 0.09 & 0.19 \\
\hline 75 & Loganiaceae & 5 & 5 & 0.08 & 0.09 & 0.17 \\
\hline 76 & Asclepiadaceae & 4 & 4 & 0.07 & 0.07 & 0.14 \\
\hline 77 & Aspleniaceae & 4 & 4 & 0.07 & 0.07 & 0.14 \\
\hline 78 & Symplocaceae & 4 & 4 & 0.07 & 0.07 & 0.14 \\
\hline 79 & Ancistrocladaceae & 3 & 3 & 0.05 & 0.06 & 0.10 \\
\hline 80 & Styracaceae & 3 & 3 & 0.05 & 0.06 & 0.10 \\
\hline 81 & Apocynaceae & 2 & 2 & 0.03 & 0.04 & 0.07 \\
\hline 82 & Aralidiaceae & 2 & 2 & 0.03 & 0.04 & 0.07 \\
\hline 83 & Dipteridaceae & 2 & 2 & 0.03 & 0.04 & 0.07 \\
\hline 84 & Podocarpaceae & 2 & 2 & 0.03 & 0.04 & 0.07 \\
\hline 85 & Pteridaceae & 2 & 2 & 0.03 & 0.04 & 0.07 \\
\hline 86 & Orchidaceae & 1 & 1 & 0.02 & 0.02 & 0.03 \\
\hline 87 & Violaceae & TOTAL & 1 & 0.02 & 0.02 & 0.03 \\
\hline
\end{tabular}

$\mathrm{D}=$ density, $\mathrm{F}=$ frequency, $\mathrm{RD}=$ relative density, $\mathrm{RF}=$ relative frequency, $\mathrm{FVI}=$ family value index 